\title{
Coupling of carbon, nitrogen and oxygen cycles in sediments from a Mediterranean lagoon: a seasonal perspective
}

\author{
K. Dedieu ${ }^{1}$, C. Rabouille ${ }^{1, *}$, F. Gilbert ${ }^{2}$, K. Soetaert ${ }^{3}$, E. Metzger ${ }^{4}$, C. Simonucci ${ }^{4}$, \\ D. Jézéquel ${ }^{4}$, F. Prévot ${ }^{4}$, P. Anschutz ${ }^{5}$, S. Hulth ${ }^{6}$, S. Ogier ${ }^{7}$, V. Mesnage ${ }^{7}$ \\ ${ }^{1}$ Laboratoire des Sciences du Climat et de l'Environnement, UMR CEA-CNRS, domaine du CNRS, av. de la Terrasse, \\ 91198 Gif sur Yvette, France \\ ${ }^{2}$ Laboratoire de Microbiologie, Géochimie et Ecologie Marines (COM), UMR CNRS 6117, Université de la Méditerranée \\ Campus de Luminy, 13288 Marseille Cedex 9, France \\ ${ }^{3}$ Netherlands Institute of Ecology, POB140, 4400 NT Yerseke, The Netherlands \\ ${ }^{4}$ Equipe de Géochimie des Eaux, Institut de Physique du Globe de Paris, Université Paris 7, 75251 Paris Cedex 05, France \\ ${ }^{5}$ Université Bordeaux 1, UMR CNRS 5805 EPOC, av. des Facultés, 33405 Talence, France \\ ${ }^{6}$ Department of Chemistry, Göteborg University, 41296 Göteborg, Sweden \\ ${ }^{7}$ UMR CNRS 6143 ‘M2C', Université de Rouen, 76821 Mont-St-Aignan, France
}

\begin{abstract}
Experimental data and simulations were used to investigate the seasonal coupling between carbon, nitrogen and oxygen cycles in marine sediments from a eutrophic shallow lagoon in the Mediterranean Sea area. A negative seasonal correlation was observed between oxygen consumption and coupled nitrification-denitrification rates in surface sediments. Elevated values of oxygen consumption rates were reached during warm periods (up to $87.7 \mathrm{mmol} \mathrm{m}^{-2} \mathrm{~d}^{-1}$ ) whereas nitrification and denitrification rates remained close to the lowest rates reported for coastal sediments (values around 0.021 to $0.35 \mathrm{mmol} \mathrm{N} \mathrm{m} \mathrm{N}^{-1}$ for nitrification and 0.014 to $0.045 \mathrm{mmol} \mathrm{N} \mathrm{m}^{-2} \mathrm{~d}^{-1}$ for denitrification). A steady-state diagenetic model closely represented the seasonal negative correlation of oxygen uptake, coupled nitrification-denitrification rates, the vertical distribution patterns of pore water oxygen and the solid phase distribution of organic carbon when nitrification inhibition by sulfide was included. Simulation adjusted to field data also highlighted the importance of oxygen penetration depth in the seasonal variation of nitrification. The modelling indicated that anaerobic metabolism was the most significant pathway (65 to $80 \%$ ) during organic matter mineralization with a clear seasonal increase during warm periods. These warm periods were also characterized by the higher benthic demand of oxygen mostly used to re-oxidize the by-products from anaerobic reactions (from 57 to $82 \%$ ), the other part being used for carbon mineralization.
\end{abstract}

KEY WORDS: Nitrogen dynamics · Carbon · Oxygen $\cdot$ Coastal sediment $\cdot$ Diagenesis modelization

\section{INTRODUCTION}

In marine sediments, the biogeochemical cycles of carbon, oxygen and nitrogen are tightly coupled (e.g. Hulthe et al. 1998, Christensen et al. 2003). When the oxygen supply or organic carbon input vary, marked changes occur in the dominant metabolic pathways of the benthic microbial processes and affect the delicate balance between the various nitrogen processes (e.g. Risgaard-Petersen et al. 1994, Rysgaard et al. 1994). Biogeochemical processes during nitrogen cycling in surface sediments of coastal marine systems include various reactions such as nitrification, denitrification, reoxidation of anaerobic byproducts by nitrate, dissimilatory reduction of nitrate (or nitrite) to ammonium (DNRA) and anaerobic ammonium oxidation by nitrite 
to dinitrogen gas (anammox) (e.g. Blackburn \& Sørensen 1988, Kuypers et al. 2003, Dalsgaard et al. 2005). Nitrification, the bacterially mediated oxidation of ammonium and nitrite to nitrate by oxygen, is the main source of nitrate in marine environments. Several studies have pointed out the occurrence of anaerobic production of nitrate by manganese oxides (Luther et al. 1997, Hulth et al. 1999, Anschutz et al. 2000, Hyacinthe et al. 2001). Sediment denitrification can occur just below the oxic-anoxic interface when oxygen is depleted by oxic mineralization (e.g. Froelich et al. 1979, Jensen et al. 1993) or in anoxic microenvironments within the oxic surface layer (Brandes \& Devol 1995). Denitrification is a key process in the sediment nitrogen cycle since it constitutes an important sink for nitrogen in organic rich sediments (e.g. Christensen et al. 1987, Devol 1991), although at least locally anammox may be as important (Dalsgaard et al. 2003). This nitrogen loss from the system can counteract the eutrophication process often occurring in shallow benthic environments (Eyre \& Ferguson 2002). Major factors regulating nitrification and denitrification are usually the availability of oxidants (oxygen, nitrite/ nitrate) and the supply of reductants such as organic material for heterotrophic denitrification or ammonium (e.g. Henriksen \& Kemp 1988, Lohse et al. 1993) as well as inhibiting metabolites such as hydrogen sulfide (Joye \& Hollibaugh 1995). The stimulation of nitrification and inhibition of denitrification by oxygen lead to a complex regulatory pattern for the coupled process of nitrification-denitrification (Kemp \& Dodds 2002). Although carbon, nitrogen and oxygen cycles are tightly coupled and strongly dependent on seasonal variations, few studies have investigated the regulatory factors in the context of temporal and spatial variability.

To elucidate the interplay between processes regulating nitrification and denitrification and their temporal and spatial variations, we explored the biogeochemical cycling of $\mathrm{C}, \mathrm{O}_{2}$ and $\mathrm{N}$ in a shallow lagoon of contrasted benthic environments and marked seasons. The Thau Lagoon in southern France is characterized by shellfish farming and a responsive drainage basin. In this lagoon, the changes in environmental conditions associated with shellfish farming and runoff from land strongly influence the nitrogen cycle at the sediment-water interface (Gilbert et al. 1997). The seasonal and spatial variations of sedimentary oxygen distributions appeared strongly related to the carbon input and temperature variations (Dedieu et al. 2007).

Using a combination of field and laboratory measurements with modelling, this temporal and spatial coupling was first investigated over different seasons at 2 stations (1 outside and 1 inside the shellfish farming area) and then explained through the identification of the various factors controlling nitrogen, carbon and oxygen dynamics. The relative importance of the main reaction pathways during organic matter mineralization was also investigated through the quantification of nitrification-denitrification rates and oxic-anoxic mineralization rates.

\section{MATERIALS AND METHODS}

Study sites. The study was carried out during 5 cruises (December 2001, April and August 2002, January and May 2003) in the Thau Lagoon, a shallow lagoon of $75 \mathrm{~km}^{2}$ located in southeastern France near Montpellier (Fig. 1). Average depth of the lagoon is $4 \mathrm{~m}$ (locally up to $10 \mathrm{~m}$ ). This lagoon is connected to the sea through the narrow channels of Sète and receives freshwater mostly from the Vène and Pallas rivers, which represent $43 \%$ of the total watershed $\left(280 \mathrm{~km}^{2}\right)$. Typical characteristics of the lagoon are related to shellfish farming activity. Activities associated with shellfish cultivation cover about $20 \%$ of the total lagoon area and produce about $35000 \mathrm{t}$ of shellfish yearly (Hamon \& Tournier 1981). This study was carried out in 2 different sampling stations, one outside (Stn C4: $43^{\circ} 24.029^{\prime} \mathrm{N}, 3^{\circ} 36.701^{\prime} \mathrm{E}$; ca. $8 \mathrm{~m}$ depth) and the other inside the shellfish park, more precisely in corridors located a few meters from mussel tables (Stn C5: $43^{\circ} 25.990^{\prime} \mathrm{N}, 3^{\circ} 39.656^{\prime} \mathrm{E}_{\text {; }}$ ca. $8 \mathrm{~m}$ depth). Shellfish hang on ropes from a support table to a depth

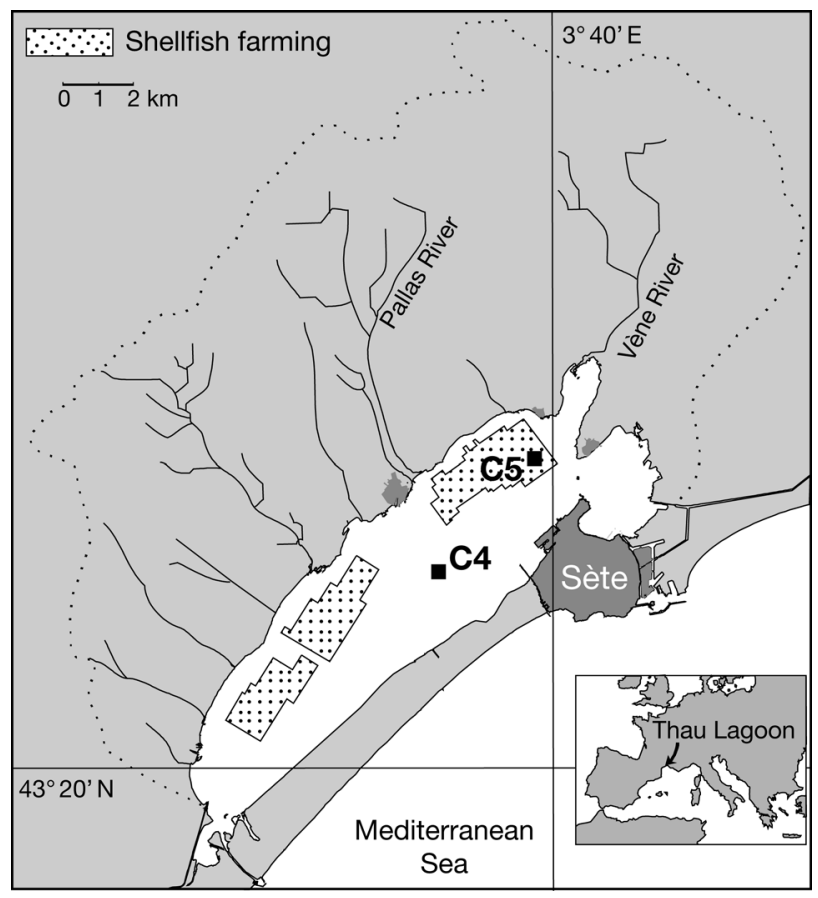

Fig. 1. Thau Lagoon: sampling sites and 2 stations; Stn C4 outside and Stn C5 inside the shellfish farming area 
of up to $1 \mathrm{~m}$ from the sediment floor. The shellfish farmers' work consists of the weekly maintenance of the production by boat. In such conditions, sediment disturbance is insignificant at Stn C5 where water column depth is high.

The sedimentary features observed on X-ray images, the grain size curve and porosity measurements roughly show the same lithological facies at both stations: a gray, silty, clay sediment with shells and shell debris, a mean grain size between 10 and $20 \mu \mathrm{m}$ (Schmidt et al. 2007) and a mean $( \pm$ SD) surface porosity of $0.90 \pm 0.05$ (Dedieu et al. 2007). Nevertheless the density variation of gray levels observed on $\mathrm{X}$-ray images is quite different along the cores. In the first $10 \mathrm{~cm}$ of Stn C4, shells are more abundant in homogeneous clay sediment. At Stn C5, sediments are made up of silty clay with small bivalve shells and have light gray levels near the interface, indicating a very fresh sedimentary deposit (Schmidt et al. 2007). This is in accordance with measurements of the Hydrogen Index (which gives a rough estimate of the organic matter quality) that revealed a more biodegradable material at this station compared with that at Stn C4 (Mesnage et al. 2007). Bioturbation rates derived from both ${ }^{234} \mathrm{Th}$ and ${ }^{7} \mathrm{Be}$ radionuclide profiles range between 1 and $10 \mathrm{~cm}^{2} \mathrm{yr}^{-1}$ at Stn C4 and 1 and $31 \mathrm{~cm}^{2} \mathrm{yr}^{-1}$ at Stn C5 with highest values observed during the warmer periods. This latter station presents a higher seasonal variability, which is probably related to its position near oyster farms. Analyses of macrobenthos (organism density, total biomass, dominant species) and sediment reworking indicated roughly similar organism density and total biomass despite a different macrobenthos community and higher and deeper benthic mixing intensities at Stn C5 $\left({ }^{210} \mathrm{~Pb}\right.$ cross-sectional profiles exhibit a wellpronounced mixed layer of $10 \mathrm{~cm}$ depth at Stn C5) (Duport et al. 2007, Schmidt et al. 2007). Both stations consisted of a classical mixture of muddy sand in sheltered areas and fine sand assemblages. At Stn C4, however, species characteristically associated with fine sand were dominant while Stn C5 was dominated by species characteristic of the muddy sand in sheltered areas. The presence of Capitella capitata at Stn C5 indicated a high level of organic material, probably in relation to the proximity of shellfish tables.

Porewater and solid phase. In situ measurements of vertical oxygen microprofiles were acquired using a microprofiler (Unisense ${ }^{\circledR}$ ) mounted on a tripodal frame and positioned by divers on the sea floor with minimum sediment disturbance (Dedieu et al. 2007). A minimum time period of 30 min was allowed to pass before starting the measurement program. After this waiting period the cylinder was lowered step-wise by a pre-programmed motorized system. Dissolved oxygen concentration was measured by polarographic oxygen microelectrodes provided with a built-in reference and an internal guard cathode (Revsbech 1989). The oxygen microsensor tip had an outer diameter of $100 \mu \mathrm{m}$, a stirring sensitivity below $1 \%$, a $90 \%$ response time below $10 \mathrm{~s}$ and a current drift of less than $2 \% \mathrm{~h}^{-1}$.

The diffusive oxygen uptake $\left(J_{\text {diff }}\right)$ of the sediments was estimated from oxygen microdistributions at the sediment-water interface using Fick's First Law of diffusion:

$$
J_{\text {diff }}=-\phi \cdot D s \cdot\left[\frac{\mathrm{dO}_{2}}{\mathrm{~d} z}\right]_{z=0}
$$

where $\phi$ is the sediment porosity, Ds the molecular diffusivity of oxygen in sediment $\left(\mathrm{cm}^{2} \mathrm{~s}^{-1}\right), z$ the depth in sediment $(\mathrm{cm})$. The inverse of the formation resistivity factor $\left(F^{-1}\right)$, measured at each depth (Dedieu et al. 2007), can be scaled to porosity using the empirical Archie relation: $F^{-1}=\phi^{m}$, where $m$ is determined experimentally depending on sediment type (Ullman \& Aller 1982). For coastal muddy sediments where porosity $\geq 0.7$, the value used for $m$ is estimated to be 2.5 to 3. Following this relation, we find that $D s=D o \phi^{m-1}$ and $\phi D s=D o \phi^{m}=D o F^{-1}$, where Do is the molecular diffusivity of oxygen in water at in situ temperature $\left(\mathrm{cm}^{2} \mathrm{~s}^{-1}\right)$. Validity of the calculations was checked using the PROFILE software (Berg et al. 1998) to calculate diffusive oxygen fluxes (Dedieu et al. 2007). A fair consistency between $J_{\text {diff }}$ calculated from the interface method and those provided by the PROFILE software appeared, with differences lower than $10 \%$ in most instances. In marine sediments, total oxygen uptake represents the oxygen balance between production and respiration through processes such as diffusive and advective exchanges and fauna-mediated oxygen uptake. A preceding study on the oxygen dynamics compared total oxygen uptake with diffusive oxygen fluxes during April 2002 and May 2003 to evaluate the importance of advective processes and bioturbation in this studied system (Dedieu et al. 2007). At Stn C4, results showed that total oxygen uptake measured in a transparent benthic chamber was 3 times greater than diffusive oxygen fluxes in April 2002, which indicates that about two-thirds of oxygen uptake was faunamediated, whereas total oxygen uptake was statistically equivalent to diffusive oxygen fluxes in May 2003. At Stn C5, average total oxygen uptake was similar to diffusive $\mathrm{O}_{2}$ fluxes in April 2002 and May 2003, indicating that the governing oxygen transport is mainly diffusive. Except at Stn C4 during April 2002, this indicates an acceptable estimation of total oxygen uptake through the determination of diffusive oxygen uptake. Because we do not have temporal variation of total oxygen uptake, we cannot extend this conclusion to the other seasons. 
Separation of the porewaters from the sediment was performed by equilibration probes (peepers) (Hesslein 1976) or by centrifugation of sectioned sediment cores. Nitrate plus nitrite and ammonium contents were determined in both stations using the Merk Spectroquant $^{\circledR} 14752$ according the method of Anderson (1979) and by flow injection analysis (FIA) according the method of Hall \& Aller (1992). Only 2 nitrate plus nitrite profiles were acquired at both stations during December 2001 (data not shown) and measurements showed very low concentrations in the pore waters at all depths $\left(\leq 1 \mu \mathrm{mol} \mathrm{l}{ }^{-1}\right)$.

During each cruise, sediments for microbial activity measurements were collected at both stations (3 samples per station) by scuba diving using PVC cores (10 cm inside diameter, $30 \mathrm{~cm}$ height). Nitrification and denitrification rates in the sediment were assessed with the acetylene-blockage method that used various partial pressures of acetylene to selectively inhibit nitrification or denitrification (Klemedtsson et al. 1988).

To measure nitrification rates, the upper $2 \mathrm{~cm}$ of each sediment was divided into 3 sets of triplicate $0.7 \mathrm{ml}$ samples and transferred into $10 \mathrm{ml}$ tubes with $2 \mathrm{ml}$ of seawater from each corresponding station. Seawater was then supplemented with chloramphenicol (final concentration, $1 \mathrm{~g} \mathrm{l}^{-1}$ ) to prevent bacterial growth during incubation. The tubes were sealed with rubber stoppers. In half of the tubes, acetylene was injected to $10 \mathrm{~Pa}$ final concentration to specifically inhibit the first step of nitrification $\left(\mathrm{NH}_{4}{ }^{+}\right.$oxidation) (Klemedtsson et al. 1990). Then all of the tubes were vortexed. Samples were incubated in the dark at the experimental temperature for $0,1,3,5$ and $8 \mathrm{~h}$. After incubation, each tube was treated with $0.1 \mathrm{ml}$ of $1 \mathrm{M} \mathrm{HgCl}_{2}$ solution. The nitrification rate was measured as the difference of $\mathrm{NO}_{3}{ }^{-}$production in both the absence and presence of acetylene.

To measure denitrification rates, subsamples $(0.7 \mathrm{ml})$ from each upper $2 \mathrm{~cm}$ of sediment were transferred into $5 \mathrm{ml}$ tubes with $2 \mathrm{ml}$ of seawater from each corresponding station. Seawater was then supplemented with chloramphenicol (final concentration, $1 \mathrm{~g} \mathrm{l}^{-1}$ ) to prevent bacterial growth during incubation. The tubes were sealed with rubber stoppers and anaerobic conditions were obtained by flushing $\mathrm{N}_{2}$ through the tube for $2 \mathrm{~min}$. Acetylene, which selectively inhibits the reduction of $\mathrm{N}_{2} \mathrm{O}$ to $\mathrm{N}_{2}$, was injected in the gas phase (final concentration, $15 \mathrm{kPa}$ ) and the tubes were vortexed. Samples were incubated in the dark at the in situ temperature for $0,1,3,5$ and $8 \mathrm{~h}$. Before analysis, each tube was treated with $0.1 \mathrm{ml}$ of $1 \mathrm{~mol} \mathrm{l}^{-1} \mathrm{HgCl}_{2}$ solution. Denitrifying activity was considered as the linear initial rate of $\mathrm{N}_{2} \mathrm{O}$ accumulation in the gas phase during incubations.
Nitrous oxide $\left(\mathrm{N}_{2} \mathrm{O}\right)$ in the tubes was determined by gas chromatography (HP5890, Series II) with an electron capture detector and an automatic injector (Dani HSS 86.50; oven at $50^{\circ} \mathrm{C}$; manifold, $50^{\circ} \mathrm{C}$; injection tube, $150^{\circ} \mathrm{C}$. Chromatographic operating conditions: oven $50^{\circ} \mathrm{C}$ i injector, $150^{\circ} \mathrm{C}$; detector, $260^{\circ} \mathrm{C}$ ). Nitrogen was used as carrier gas at a flow rate of $20 \mathrm{ml} \mathrm{min}^{-1}$. Porewater nitrate was reduced on a $\mathrm{Cu}-\mathrm{Cd}$ column adapted to Technicon II according to Treguer \& Le Corre (1975). Nitrite concentrations were determined colorimetrically by the method of Bendschneider \& Robinson (1972).

Total organic carbon (TOC) content ( $\%$ by weight) of the investigated sediments was measured with RockEval pyrolsis (Espitalié et al. 1985) and a RE6 device (Vinci Technologies). The analyses were carried out on $100 \mathrm{mg}$ of dried and homogenized samples with a temperature program starting from $300^{\circ} \mathrm{C}$ for $20 \mathrm{~min}$ and increasing up to $600^{\circ} \mathrm{C}$ at $25^{\circ} \mathrm{C} \mathrm{m^{-1 }}$ under a $\mathrm{N}_{2}$ flow, followed by oxidation at $600^{\circ} \mathrm{C}$ for 7 min under an oxygen flow. TOC was only measured during an intermediate cruise of April 2002 at both stations.

Diagenetic modelling. A steady state version of a numerical coupled diagenetic model, OMEXDIA (Soetaert et al. 1996), has been applied to the measured profiles of oxygen, ammonium and TOC to estimate the seasonal variation of $\mathrm{C}$ and $\mathrm{N}$ cycling, the rates of total carbon oxidation and the relative contribution of the majors pathways linked to organic matter mineralization as a function of station and season.

Description of model: OMEXDIA is a numerical nonlinear coupled model based on the 1-dimensional diagenetic equations as presented by Berner (1980) and Boudreau (1997). Solutes are transported by molecular diffusion, whereas the solid phase is transported by advection, compaction and bioturbation. By describing aerobic carbon mineralization, nitrification and denitrification and combining anaerobic mineralization processes, the model generates profiles of oxygen, nitrate, ammonium, Oxygen Demand Units (ODU; i.e. the amount of oxygen necessary to reoxidize reduced counterparts from anaerobic mineralization) and carbon.

Solid phase organic carbon is modelled as 2 degradable fractions characterized by different first order degradation rates (labile and more refractory) and C:N ratios to account for decreasing organic matter reactivity with sediment depth. Mineralization rates are mainly limited both by carbon (first order kinetics) and oxidant availability (Michaelis-Menten type kinetics). Nitrification of ammonium was described separately, which allowed a dynamic coupling of nitrification with anoxic mineralization.

Microbial processes: The idealized model reactions considered to influence the distribution of porewater solutes were (Soetaert et al. 1996): 
Oxic respiration: $\left(\mathrm{CH}_{2} \mathrm{O}\right)_{X}\left(\mathrm{NH}_{3}\right)_{V}\left(\mathrm{H}_{3} \mathrm{PO}_{4}\right)+\mathrm{XO}_{2} \rightarrow$ $x \mathrm{CO}_{2}+y \mathrm{NH}_{3}+\mathrm{H}_{3} \mathrm{PO}_{4}+x \mathrm{H}_{2} \mathrm{O}$,

Nitrification: $\mathrm{NH}_{3}+2 \mathrm{O}_{2} \rightarrow \mathrm{HNO}_{3}+\mathrm{H}_{2} \mathrm{O}$, Denitrification: $\left(\mathrm{CH}_{2} \mathrm{O}\right)_{X}\left(\mathrm{NH}_{3}\right)_{Y}\left(\mathrm{H}_{3} \mathrm{PO}_{4}\right)+0.8 x \mathrm{HNO}_{3} \rightarrow$ $x \mathrm{CO}_{2}+y \mathrm{NH}_{3}+0.4 x \mathrm{~N}_{2}+\mathrm{H}_{3} \mathrm{PO}_{4}+1.4 x \mathrm{H}_{2} \mathrm{O}$,

Anoxic respiration: $\left(\mathrm{CH}_{2} \mathrm{O}\right)_{x}\left(\mathrm{NH}_{3}\right)_{y}\left(\mathrm{H}_{3} \mathrm{PO}_{4}\right)+$ an oxidant $\rightarrow x \mathrm{CO}_{2}+y \mathrm{NH}_{3}+\mathrm{H}_{3} \mathrm{PO}_{4}+x \mathrm{ODU}+x \mathrm{H}_{2} \mathrm{O}$, Reoxidation of reduced compounds by oxygen:

$\mathrm{ODU}+\mathrm{O}_{2} \rightarrow$ an oxidant,

where the stoichiometry of the organic matter is represented by the coefficients $x$ (molar C:P ratio) and $y$ (molar N:P ratio) and ODU. As described in Soetaert et al. (1996), we assigned to ODU the diffusion coefficient of hydrogen sulfide (HS-) as it is the byproduct of sulfate reduction, the most prominent anoxic mineralization process in coastal marine sediments. This is particularly adapted to the benthic environment being studied where sulfate reduction is the dominant anoxic process compared to manganese or iron oxide reduction (Metzger et al. 2007).

As suggested by Joye \& Hollibaugh (1995) the presence of sulfide may inhibit nitrification and, consequently, coupled denitrification. A possible control of the nitrogen cycle by sulfide in the sediments close to the shellfish zone was then tested with the diagenetic model by adding a coefficient of sulfur inhibition (ODU Inhibition Factor) in the initial nitrification equation that becomes (Eq. 1):

$$
\begin{aligned}
& \text { ODU Inhibitor Factor }=1-\frac{\mathrm{ODU}}{\mathrm{ODU}+K i n_{\mathrm{ODU}}^{\mathrm{Nit}}} \\
& \mathrm{NH}_{3 \text { oxid }}=\left[R_{\text {nitrit }} \times \mathrm{NH}_{3} \times \frac{\mathrm{O}_{2}}{\mathrm{O}_{2}+K s_{\text {Nitrif }}^{\mathrm{O}_{2}}}+\right. \\
& \left.\left(\mathrm{OxiCMin}_{1} \times \gamma_{\mathrm{TOC}_{1}}^{\mathrm{N}}+\mathrm{OxiCMin}_{2} \times \gamma_{\mathrm{TOC}_{2}}^{\mathrm{N}}\right) \times \frac{(1-\Phi)}{\Phi}\right] \\
& \times \text { ODU Inhibitor Factor }
\end{aligned}
$$

where $\mathrm{Kin}_{\mathrm{ODU}}^{\mathrm{Nit}}$ is the half-saturation constant for nitrification inhibition by ODU $\left(\mu_{\mathrm{molO}} \mathrm{l}^{-1}\right)$, OxicMin ${ }_{1}$ is the amount of labile carbon oxidized by oxygen and $\mathrm{OxicMin}_{2}$ is the amount of refractory carbon oxidized by oxygen.

Model calibration: To calibrate the model, in situ oxygen, nitrate, ammonium, TOC and ODU concentrations with depth in the sediment were reproduced and the goodness of fit was evaluated by visually comparing the profiles obtained from the models with those that were measured. Goodness of fit was also evaluated with the model cost function which quantifies the discrepancy between observed data and modelled values. The lower the cost function was, the better the model described the data. Model calculations were performed using parameters measured in the field such as sedimentation rates, macrofaunal reworking activities (bioturbation), porosity profiles, bottom water temperature and ion concentrations in bottom and intersitial waters $\left(\mathrm{O}_{2}, \mathrm{NO}_{3}{ }^{-}, \mathrm{NH}_{4}{ }^{+}, \mathrm{H}_{2} \mathrm{~S}, \mathrm{SO}_{4}{ }^{2-}, \mathrm{Mn}^{2+}\right.$, $\mathrm{Fe}^{2+}$ ). Biogeochemical parameters such as $Q_{10}$ and $\mathrm{NH}_{4}$ adsorption were obtained from literature, whereas the mean carbon flux, proportion of labile and refractory carbon, and the limitation and inhibition constants were adjusted to match both the observed concentration profiles of $\mathrm{O}_{2}$, organic $\mathrm{C}, \mathrm{NO}_{3}{ }^{-}$and $\mathrm{NH}_{4}{ }^{+}$and the measured rates of oxygen uptake, nitrification and denitrification. The list and sources of all fixed parameters used in the model from field measurements are presented in Table 1. Those from literature and those obtained by calibration are presented in Table 2 .

The bottom water nitrate concentration was arbitrarily fixed at $1 \mu_{\mathrm{mol}} \mathrm{l}^{-1}$ according to the nitrate plus nitrite profiles acquired during the December cruise at both stations. Finally, our calibration exercise aimed at providing the best fits to concentration versus depth profiles. The relative contribution of the different pathways during organic matter degradation was determined from these simulation results.

\section{RESULTS}

\section{In situ temperature and bottom water oxygenation}

The bottom water temperature followed a seasonal pattern and varied from $9.6^{\circ} \mathrm{C}$ in December 2001 to $23^{\circ} \mathrm{C}$ in August 2002, dropping to a minimum of $8.5^{\circ} \mathrm{C}$ in January 2003. Mean $( \pm \mathrm{SD})$ oxygen concentration in the bottom water varied from $160 \pm 8$ to $320 \pm$ $16 \mu \mathrm{mol} \mathrm{l}^{-1}$ at Stn C4 and from $194 \pm 8$ to $315 \pm 8 \mu \mathrm{mol} \mathrm{l} \mathrm{l}^{-1}$ at Stn C5 (Dedieu et al. 2007). Overall, the values measured during the cold periods corresponded to $100 \%$ saturation, whereas values measured during warm periods (August 2002 and May 2003) varied from $100 \%$ to $68 \%$ (May 2003 at Stn C4). Significant variability of measured oxygen concentration values in August 2002 and May 2003 indicate short-term variations of oxygen concentration in bottom waters, linked to stratification and vertical mixing of the water column. Except in May 2003, bottom water oxygenation was similar outside and inside the shellfish culture areas.

\section{Porewater and solid phase distributions}

A total of 85 oxygen profiles were measured at both stations during the 5 investigative cruises (Dedieu et al. 2007). The decrease of oxygen concentration with depth and the absence of oxygen over-saturation at the sediment interface indicate the dominance of benthic respiration overall. A microphytobenthos community could be present in such a shallow lagoon. However, in 


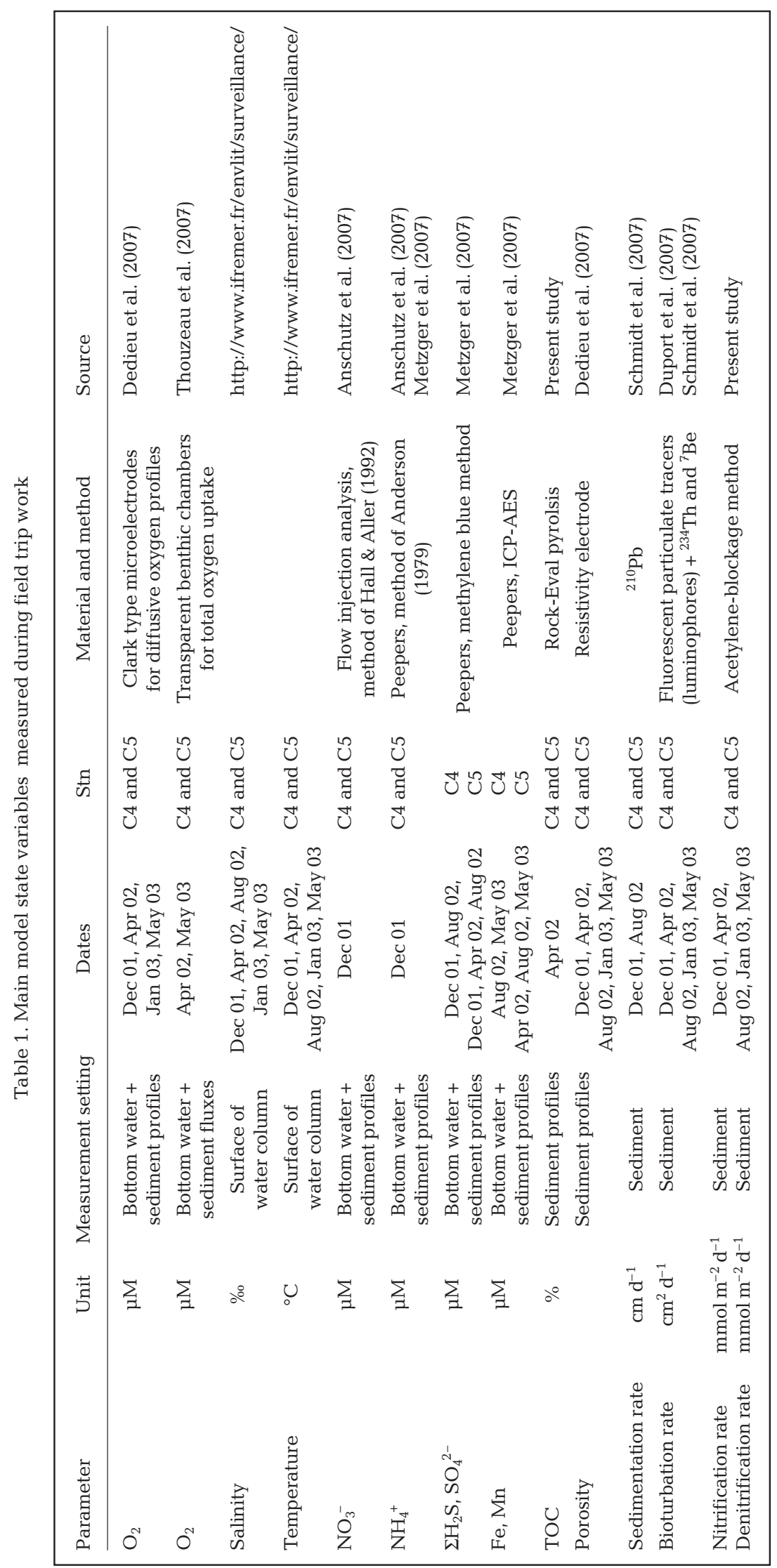

the Thau Lagoon, which was very turbid throughout the periods investigated, little microbenthos was found and no benthic oxygen production was measured at the sediment-water interface. Indeed, results from the LI-COR quantum sensor (LI192SA), deployed inside clear chambers to record the amount of photosynthetically active radiation (PAR, 400-700 nm) available for the enclosed photosynthetic organisms, revealed extremely low irradiance values at both stations $(<42 \mu \mathrm{mol}$ quanta $\mathrm{m}^{-2} \mathrm{~s}^{-1}$ ) (Thouzeau et al. 2007). By comparison, irradiance measurements in a shallower site of benthic macroalgal photosynthesis, located on the northern fringe of the shellfish farming area $(2.6 \mathrm{~m}$ deep), were 333 and $591 \mu \mathrm{mol}$ quanta $\mathrm{m}^{-2}$ $\mathrm{s}^{-1}$ in April 2002 and May 2003, respectively. According to these low measured values of photosynthetically active radiation, microbenthos production was probably inhibited by water turbidity rather than frame shading. Therefore, the diurnal patterns in the oxygen profiles may not constitute a significant factor of heterogeneity. Note that the investigated sediments at Stn C5 located in corridors a few $m$ from mussel tables were not shaded by the farming setup.

Across all profiles, oxygen penetration depths ranged from 0.4 to $5.6 \mathrm{~mm}$ with an annual average of 2.9 and $1.2 \mathrm{~mm}$ at Stns C4 and C5, respectively. The shallowest oxygen penetration depth was measured during the warm periods of August 2002 and May 2003 at both stations. This seasonal variation correlated well with the temperature increase and the bottom water oxygen decrease, which corresponded to a narrowing of the oxic zone. At the dm scale (corresponding to the distance between electrodes) oxygen microprofiles from each deployment showed a spatial heterogeneity illustrated by different oxygen gradients and penetration depths. The presence of an oxygen peak at depth in the December 2001 Stn C4 profile certainly indicates the presence of biological structures, and the irregular shape of some oxygen profiles, especially at Stn C5 in May 2003, may be associated with the higher sediment reworking activity during the warm periods. 
Table 2. Model parameters (see Soetaert et al. 1996). * : obtained by calibration; bold: fixed through known in situ conditions at both stations (others obtained from literature). Oxygen Demand Units (ODU) correspond to reduced byproducts reoxidized by $\mathrm{O}_{2}$ when diffusing to the oxic zone

\begin{tabular}{|c|c|c|c|}
\hline Parameter name & Unit & Value & Description \\
\hline MeanCarbonFlux & 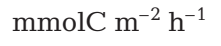 & * & Mean carbon deposited on the sea floor \\
\hline PartCarbonFluxFast & $\%$ & * & Percentage of labile carbon \\
\hline MeanBottomOxygen & $\mu \mathrm{mol} \mathrm{l} \mathrm{l}^{-1}$ & & Mean $\mathrm{O}_{2}$ concentration in overlying water \\
\hline MeanBottomNitrate & $\mu \mathrm{mol} \mathrm{l} \mathrm{l}^{-1}$ & & Mean $\mathrm{NO}_{3}$ concentration in overlying water \\
\hline MeanBottomAmmonium & $\mu \mathrm{mol} \mathrm{l} \mathrm{l}^{-1}$ & & Mean $\mathrm{NH}_{4}$ concentration in overlying water \\
\hline $\mathrm{MeanBottomSO}_{2}$ & $\mu \mathrm{mol} \mathrm{l} \mathrm{l}^{-1}$ & & Mean $\mathrm{SO}_{2}$ concentration in overlying water \\
\hline MeanBottomH $\mathrm{H}_{2} \mathrm{~S}$ & $\mu \mathrm{mol} \mathrm{l} \mathrm{l}^{-1}$ & & Mean $\Sigma \mathrm{H}_{2} \mathrm{~S}$ concentration in overlying water \\
\hline $\mathrm{Q}_{10} \mathrm{DEGsed}$ & - & 2.5 & $Q_{10}$ factor for mineralization \\
\hline TOCinfsed & $\%$ & & Organic carbon concentration at depth \\
\hline MeanBioturbation & $\mathrm{cm}^{2} \mathrm{~d}^{-1}$ & & Bioturbation coefficient \\
\hline SedimentationRate & $\mathrm{cm} \mathrm{d}^{-1}$ & & Vertical accumulation at depth \\
\hline MeanBottomTemperature & ${ }^{\circ} \mathrm{C}$ & & Mean temperature in overlying water \\
\hline $\mathrm{NH}_{4}$ Adsorption & - & 1.3 & Adsorption coefficient for ammonium \\
\hline$R_{\text {nitrit }}$ & $d^{-1}$ & ${ }^{*}$ & Maximal nitrification rate \\
\hline$R_{\text {ODUoxid }}$ & $d^{-1}$ & * & Maximal rate of oxidation of reduced ODU \\
\hline cFDET20sed & $\mathrm{d}^{-1}$ & * & Degradation constant of fast decay carbon $\left(20^{\circ} \mathrm{C}\right)$ \\
\hline cSDET20sed & $\mathrm{d}^{-1}$ & * & Degradation constant of slow decay carbon $\left(20^{\circ} \mathrm{C}\right)$ \\
\hline$K s_{\text {Nitrif }}^{\mathrm{O}_{2}}$ & $\mu \mathrm{mol} \mathrm{O} \mathrm{I}^{-1}$ & * & Half-saturated $\mathrm{O}_{2}$ concentration for nitrification limitation \\
\hline $\operatorname{Kin}_{\mathrm{ODU}}^{\mathrm{Nit}}$ & $\mu \mathrm{mol} \mathrm{ODU} \mathrm{l^{-1 }}$ & * & Half-saturated ODU concentration for nitrification inhibition \\
\hline$K s_{\text {OxicMin }}^{\mathrm{O}_{2}}$ & $\mu \mathrm{mol} \mathrm{O} \mathrm{I}^{-1}$ & * & Half-saturated $\mathrm{O}_{2}$ concentration for limitation of ODU oxidation \\
\hline$K s_{\text {ODUoxid }}^{\mathrm{O}_{2}}$ & $\mu \mathrm{mol} \mathrm{O} \mathrm{l}^{-1}$ & * & Half-saturated $\mathrm{O}_{2}$ concentration for oxic mineralization limitation \\
\hline$K s_{\text {Denitrif }}^{\mathrm{NO}_{3}}$ & $\mu \mathrm{mol} \mathrm{NO} \mathrm{N}^{-1}$ & * & Half-saturated $\mathrm{NO}_{3}$ concentration for denitrification limitation \\
\hline$K_{\text {Kin }}^{\text {Denit }}$ & $\mu \mathrm{mol} \mathrm{O} \mathrm{l}^{-1}$ & * & Half-saturated $\mathrm{O}_{2}$ concentration for denitrification inhibition \\
\hline $\mathrm{Kin}_{\mathrm{AnoxicMin}}^{\mathrm{NO}_{3}}$ & $\mu \mathrm{mol} \mathrm{NO} \mathrm{N}^{-1}$ & * & Half-saturated $\mathrm{NO}_{3}$ concentration for inhibition \\
\hline $\mathrm{Kin}_{\text {AnoxicMin }}^{\mathrm{O}_{2}}$ & $\mu \mathrm{mol} \mathrm{O} \mathrm{l}^{-1}$ & * & Half-saturated $\mathrm{O}_{2}$ concentration for anoxic mineralization inhibition \\
\hline$\gamma_{\mathrm{C}}^{\mathrm{OX}}$ & $\mathrm{molOX} / \mathrm{molC}$ & 1 & 106 mole $\mathrm{O}_{2}$ per 106 mole of $\mathrm{C}$ mineralized \\
\hline$\gamma_{\mathrm{C}}^{\mathrm{ODU}}$ & $\mathrm{molODU} / \mathrm{molC}$ & 1 & 106 mole ODU per 106 mole of C oxidized \\
\hline$\gamma_{\mathrm{TOC}_{1}}^{\mathrm{N}}$ & $\mathrm{molN} / \mathrm{molC}$ & 0.1509 & Mole of $\mathrm{NH}_{3}$ per mole of fast decay $\mathrm{C}$ oxidized \\
\hline$\gamma_{\mathrm{TOC}_{2}}^{\mathrm{N}}$ & $\mathrm{molN} / \mathrm{molC}$ & 0.1000 & Mole of $\mathrm{NH}_{3}$ per mole of slow decay $\mathrm{C}$ oxidized \\
\hline$\gamma_{\mathrm{NO}_{3}}^{\mathrm{C}}$ & $\mathrm{molNO}_{3} / \mathrm{molC}$ & 0.8 & Mole of $\mathrm{NO}_{3}$ per mole of $\mathrm{C}$ during denitrification \\
\hline$\gamma_{\mathrm{O}_{2}}^{\mathrm{C}}$ & $\mathrm{molO}_{2} / \mathrm{molN}$ & 2 & Mole of $\mathrm{O}_{2}$ per mole of $\mathrm{N}$ during nitrification \\
\hline
\end{tabular}

Ammonium profiles showed strong spatial heterogeneity between seasons and stations, with higher content evident in December 2001 and at Stn C5 inside the shellfish area (Fig. 2a,b). At Stn C5, concentrations increased just below the sediment-water interface to reach approximately $600 \mu \mathrm{mol} \mathrm{\textrm {l } ^ { - 1 }}$ at the $20 \mathrm{~cm}$ depth. At Stn C4, outside the shellfish area, profiles show a large seasonal variation with ammonium present just below the sediment-water interface in December 2001, whereas it remained below 30 to $40 \mu \mathrm{mol} \mathrm{l}^{-1}$ in the first $20 \mathrm{~cm}$ in August 2002. In May 2003, no ammonium profiles were obtained. In the overlying water, concentrations always remained below the analytical limit of detection (i.e. approximately $1 \mu \mathrm{mol} \mathrm{l}^{-1}$ ).

The 2 available TOC profiles measured in April 2002 were used for all model calculations (Fig. 2a,b). At Stn C5, TOC content in the solid phase of the sediment decreased sharply from $4.4 \%$ at the top of the core to
$3.3 \%$ at $1.75 \mathrm{~cm}$ depth and $1.7 \%$ at $7.5 \mathrm{~cm}$. Below $7.5 \mathrm{~cm}$, TOC content remained constant. At Stn C4, TOC content increased slightly from $3 \%$ at the top of the core to $3.2 \%$ at $1.75 \mathrm{~cm}$ depth, decreasing thereafter to $2.6 \%$ at $7.5 \mathrm{~cm}$. Below this depth, TOC content remained constant down to $10.5 \mathrm{~cm}$ depth.

ODU profiles were calculated by multiplying $\Sigma \mathrm{H}_{2} \mathrm{~S}$ concentration by 2 as each sulfide requires $2 \mathrm{O}_{2}$ to reoxidize and thus, 2 ODUs. $\mathrm{Fe}^{2+}$ and $\mathrm{Mn}^{2+}$ were neglected as they represent less than $10 \%$ of $\Sigma \mathrm{H}_{2} \mathrm{~S}$ concentration and represent half an ODU for $\mathrm{Mn}^{2+}$ and quarter of an ODU for $\mathrm{Fe}^{2+}$ due to stoechiometric reactions (Soetaert et al. 1996). The ODU profiles, obtained from porewater sulfide content in December 2001 and August 2002 (Metzger et al. 2007), showed differences between the stations and a marked temporal variation. At Stn C4, ODU appeared at a depth of $30 \mathrm{~cm}$ in December 2001 and at a much shallower depth in 

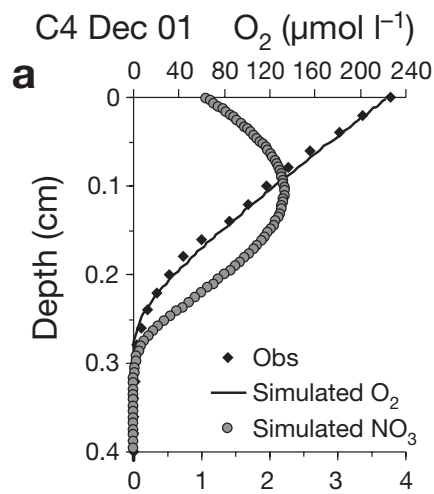

C4 Aug 02

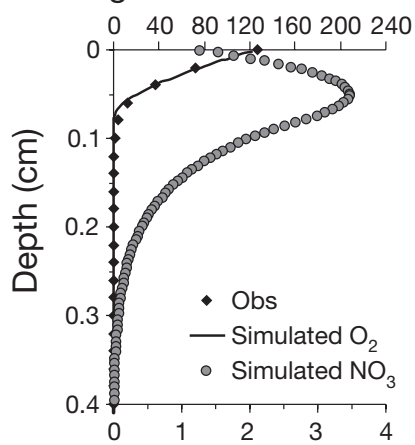

C4 May 03

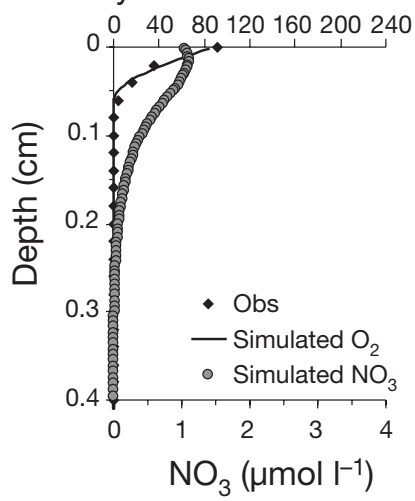

$\mathrm{NH}_{4}^{+}\left(\mu \mathrm{mol} \mathrm{I} \mathrm{l}^{-1}\right)$
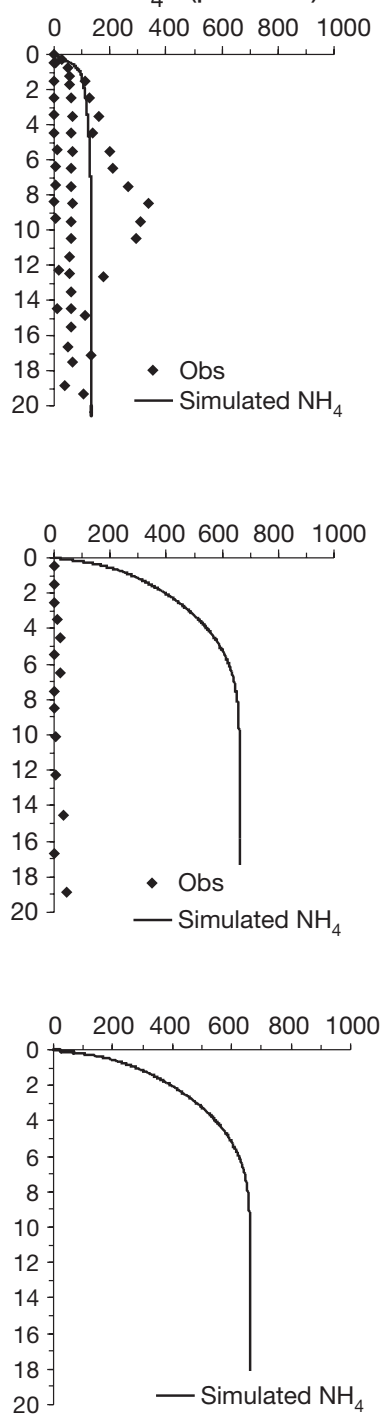

TOC (\%)

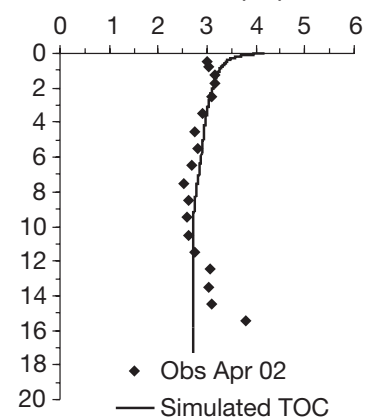

- Simulated TOC
ODU $\left(\mu \mathrm{mol} \mathrm{I} \mathrm{I}^{-1}\right)$

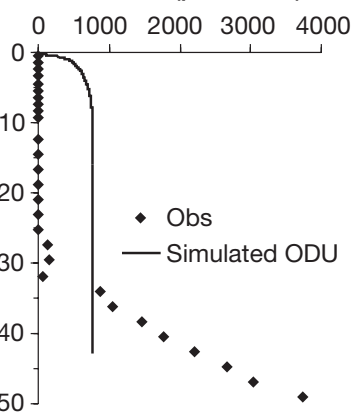

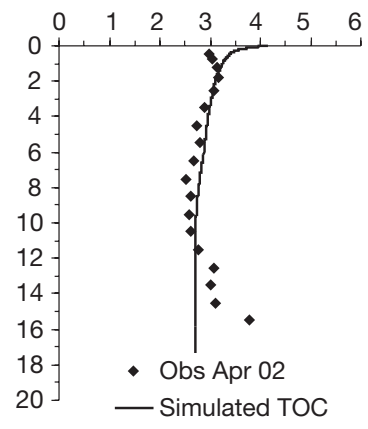

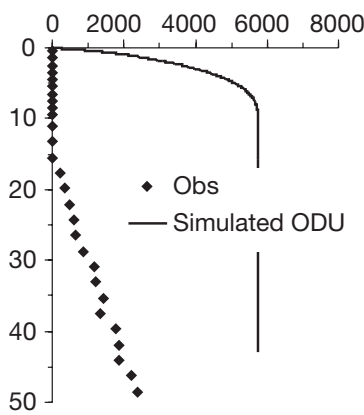

Fig. 2. (Above and facing page). In situ ( $\bullet$ ) and modeled (-) oxygen, ammonium, TOC, ODU and (O) simulated nitrate profiles at (a) Stn C4 and (b) Stn C5 during December 2001, August 2002 and May 2003. TOC profile measured during an intermediate cruise in April 2002

August 2002, whereas at Stn C5 sulfides were observed at a depth less than $10 \mathrm{~cm}$.

\section{Nitrification, denitrification and oxygen uptake rates}

Mean $( \pm \mathrm{SD})$ annual nitrification rates were $0.35 \pm 0.05$ and $0.021 \pm 0.004 \mathrm{mmol} \mathrm{N} \mathrm{m}^{-2} \mathrm{~d}^{-1}$ at Stns C4 and C5, respectively, and mean annual denitrification rates were $0.045 \pm 0.007$ and $0.014 \pm 0.004 \mathrm{mmol} \mathrm{N} \mathrm{m}^{-2} \mathrm{~d}^{-1}$, respectively (Fig. 3). Nitrification and denitrification rates were close to the lowest reported for most coastal marine and estuarine sediments (ca. 0.3 to $17.2 \mathrm{mmol} \mathrm{N} \mathrm{m}^{-2} \mathrm{~d}^{-1}$ for nitrification and ca. 0.02 to $30.2 \mathrm{mmol} \mathrm{N} \mathrm{m}^{-2} \mathrm{~d}^{-1}$ for denitrification) (e.g. Rysgaard et al. 1996, Usui et al. 2001, Christensen et al. 2003). A large gradient of nitrification and denitrification activity appeared at the lagoon scale with significantly higher nitrification and denitrification rates occurring outside (Stn C4) than inside (Stn C5) the farming zone. Outside the shellfish area, nitrification rates decreased from December 2001 to August 2002. In January 2003, nitrification reached its highest rate $\left(0.60 \pm 0.05 \mathrm{mmol} \mathrm{N} \mathrm{m}^{-2} \mathrm{~d}^{-1}\right)$. The seasonal variation of denitrification followed a similar pattern with higher values during the cold periods (December 2001, April 2002 and January 2003). At the station inside the 

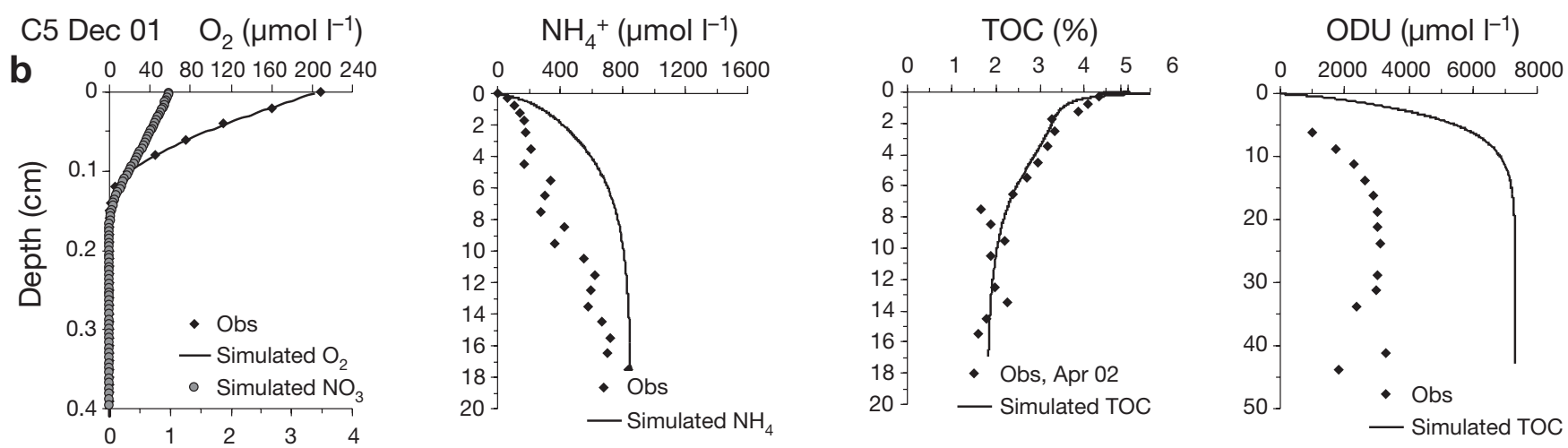

C5 Aug 02
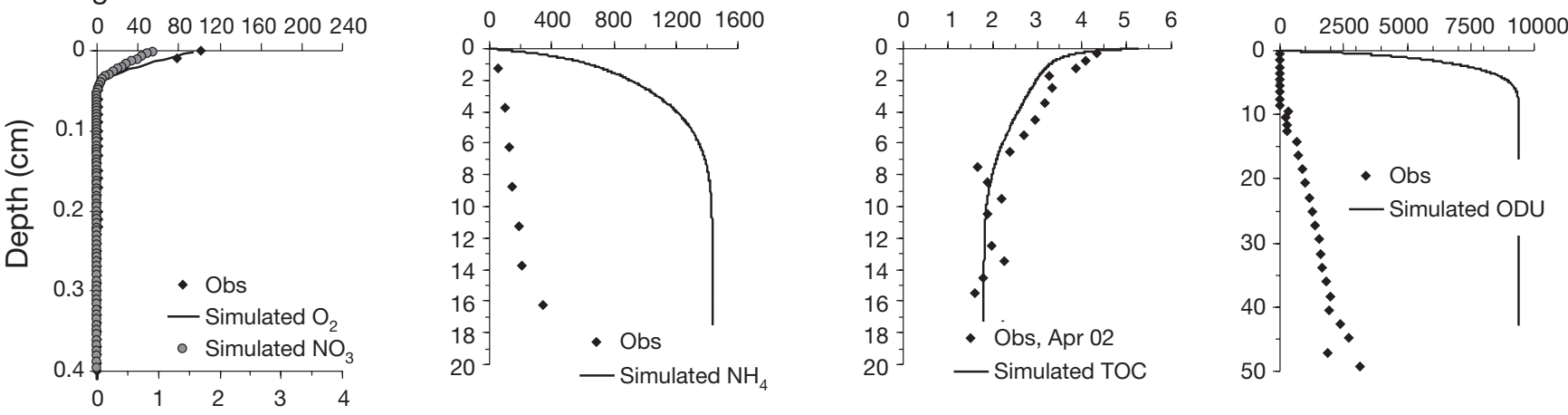

C5 May 03
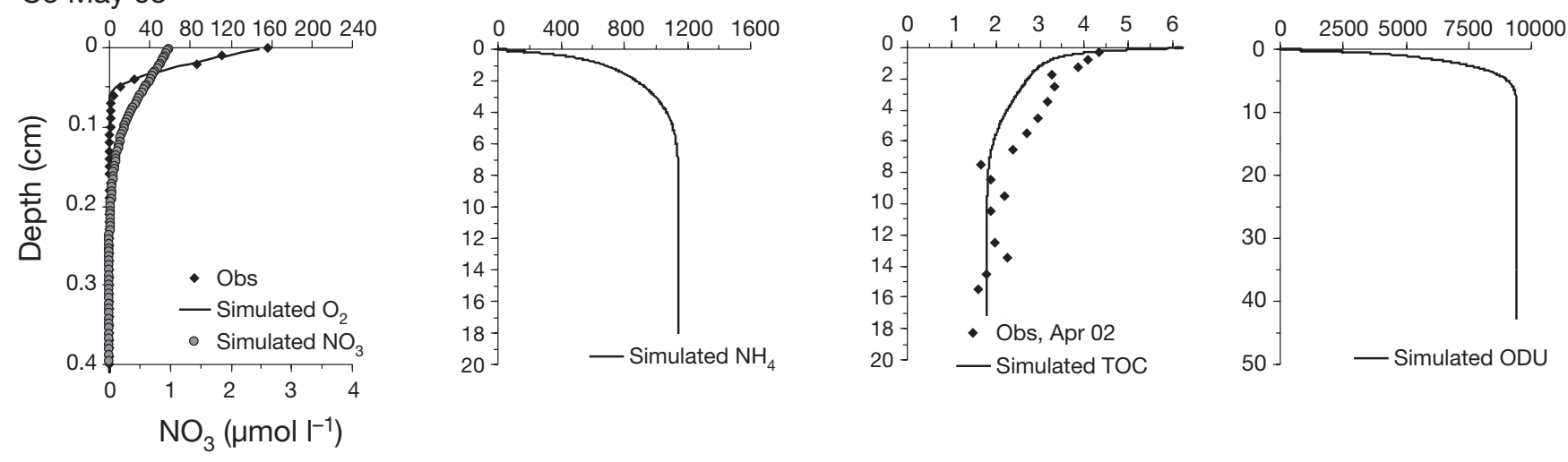

Fig. 2 (continued)

farming zone, a similar seasonal variation was evident with the highest nitrification and denitrification rates measured in December 2001 and January 2003.

A seasonal oxygen pattern emerged with maximum values of diffusive oxygen uptake through the sediment-water interface occurring in August 2002 and May 2003 at both stations, whereas the lowest oxygen uptake rates occurred during the cold periods (Fig. 3). Mean $( \pm \mathrm{SD})$ values varied from $8.6 \pm 2.1$ (January 2003 ) to $30.7 \pm 8.3$ (May 2003) $\mathrm{mmol} \mathrm{m}^{-2} \mathrm{~d}^{-1}$ at Stn C4 and from $36.8 \pm 18.5$ (December 2001) to $87.7 \pm 40.8$ (May 2003) mmol m ${ }^{-2} \mathrm{~d}^{-1}$ at Stn C5. A biogeochemical gradient at the lagoon scale then appeared between the 2 stations, with diffusive oxygen uptake rates ca. 2 to 3 times higher at Stn C5, located under the shellfish parks and subjected to larger biodeposition, than at Stn C4 outside the shellfish farming area. Deposition of higher organic matter (OM) quality and quantity at Stn C5 would explain the larger oxygen demand and aerobic respiration rates compared with that at Stn C4 (Dedieu et al. 2007). At a smaller scale, oxygen flux scatter at Stn C5 appeared significant especially during warm periods; a flux scatter factor of 6.6 in May 2003 and 4 in August 2002 was found between the minimum and maximum values of those months. This spatial heterogeneity could be linked to small scale 

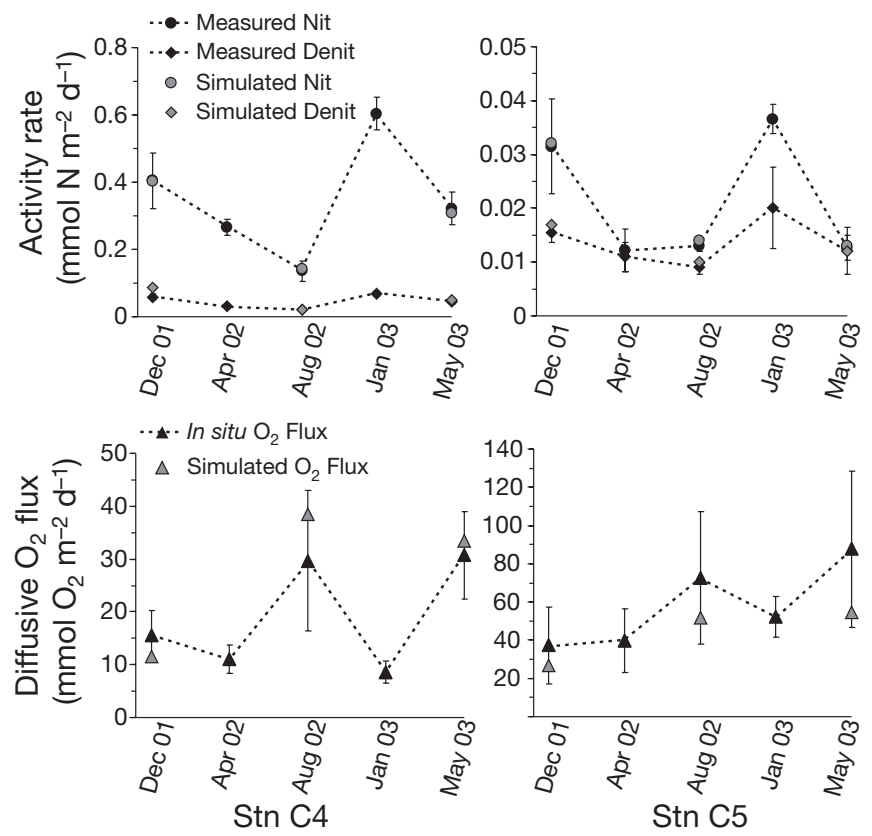

Fig. 3. Comparison of simulated $(0, \Delta, \diamond)$ nitrification, denitrification and diffusive oxygen fluxes rates with those calculated from measured in situ oxygen profiles or sediment incubations $(\bullet, \bullet, \bullet)$ at Stns C4 and C5. In situ nitrification and denitrification rates assessed using the acetylene-blockage

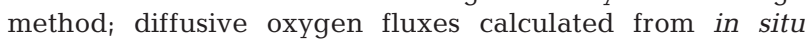
microprofiles

processes such as horizontal diffusion of oxygen from the benthic reworking activity. Note that because we used the diffusive fluxes calculation, we did not include rare bioturbated profiles (erratic shapes) in this study. In the previous study of Dedieu et al. (2007), statistical evaluation (Kruskal-Wallis test) of the oxygen flux heterogeneity inside stations and between seasons showed a clear difference between oxygen fluxes of cold and warm periods at Stn C4 (95\% of confidence level). Stn C5 showed a different pattern, with oxygen fluxes statistically grouped in a single population. From the results, it appeared that a clear seasonal variation existed at Stn C4, whereas a large spatial heterogeneity hiding the temporal variability occurred at Stn C5.

\section{Major model outputs}

The first tests conducted without sulfide inhibition showed larger nitrification and denitrification rates than those measured experimentally (Table 3). The higher disparity appeared for the nitrification rate at Stn C5 (model output $=1.42 \mathrm{mmol} \mathrm{N} \mathrm{m}^{-2} \mathrm{~d}^{-1}$ and mean annual nitrification $=0.021 \pm 0.004 \mathrm{mmol} \mathrm{N} \mathrm{m}^{-2} \mathrm{~d}^{-1}$ ). A possible control of the nitrogen cycle by sulfide was
Table 3. Model nitrification and denitrification rates calculated with or without a sulfur inhibition coefficient into the initial nitrification equation. Tests were carried out under measured $\mathrm{O}_{2 \mathrm{bw}}\left(\mu \mathrm{mol} \mathrm{O} \mathrm{O}^{-1}\right)$ and calculated $\mathrm{C}_{\text {flux }}\left(\mathrm{mmol} \mathrm{C} \mathrm{m} \mathrm{m}^{-2} \mathrm{~d}^{-1}\right)$ in August 2002. Nitrification and denitrification rates are expressed in mmol $\mathrm{N} \mathrm{m}^{-2} \mathrm{~d}^{-1}$

\begin{tabular}{|lccc|}
\hline & & $\begin{array}{c}\text { With } \mathrm{HS}^{-} \\
\text {inhibition }\end{array}$ & $\begin{array}{c}\text { Without HS } \\
\text { inhibition }\end{array}$ \\
\hline Stn C4 & Nitrification & 0.143 & 1.834 \\
$\left(\mathrm{C}_{\mathrm{flux}}=55.2\right)$ & Denitrification & 0.020 & 0.173 \\
$\left(\mathrm{O}_{2 \mathrm{bw}}=130\right)$ & & & \\
$\mathbf{S t n} \mathbf{C 5}$ & Nitrification & 0.014 & 1.416 \\
$\left(\mathrm{C}_{\mathrm{flux}}=108\right)$ & Denitrification & 0.009 & 0.010 \\
$\left(\mathrm{O}_{2 \mathrm{bw}}=105\right)$ & & & \\
\hline
\end{tabular}

then tested with the diagenetic model by adding a coefficient of sulfur inhibition. Results showed that nitrification and denitrification rates were lower in the sulfide-enriched sediment and closer to measured rates indicating the natural potential of these processes in the sediments studied. Fig. 4 illustrates the good agreement between measured and calculated seasonal variations of nitrification, denitrification and oxygen fluxes when sulfide inhibition was added.

From this model adjustment, the major model outputs showed that diffusive oxygen fluxes and carbon deposition rates were 2 and 3 times higher at the station inside the shellfish park than at the station outside (Table 4). In December 2001, a high proportion of labile carbon was found at both stations, $95 \%$ at Stn C4 and $80 \%$ at Stn C5, with degradation constant values (at $20^{\circ} \mathrm{C}$ ) of 0.06 and $0.1 \mathrm{~d}^{-1}$, respectively. In August 2002 and May 2003, the labile carbon fraction exceeded the slowly degradable one at both stations, $90 \%$ at Stn C4 and 80 to $85 \%$ at Stn C5, but the mineralization constant value (at $20^{\circ} \mathrm{C}$ ) of the labile material at both stations was similar at $0.1 \mathrm{~d}^{-1}$.

\section{DISCUSSION}

\section{Seasonal nitrogen dynamics}

Measurements of nitrification and denitrification revealed a seasonal pattern with maximum rates occurring in December 2001 and January 2003. A negative correlation between diffusive oxygen uptake and nitrification-denitrification rates appeared at both stations; while maximum oxygen fluxes were reached in August 2002 and May 2003, the same periods had the minimum nitrification and denitrification rates (Fig. 3). Several factors are known to influence nitrogen and oxygen dynamics, such as temperature, bottom water oxygenation, oxic zone thickness and organic matter 


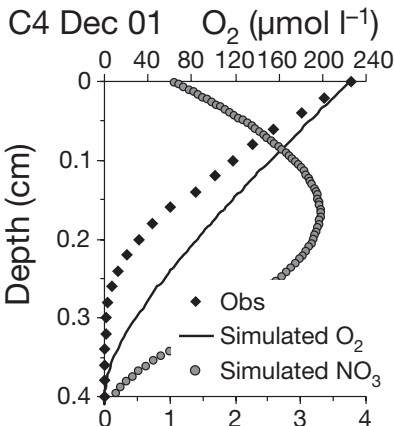

C4 Aug 02

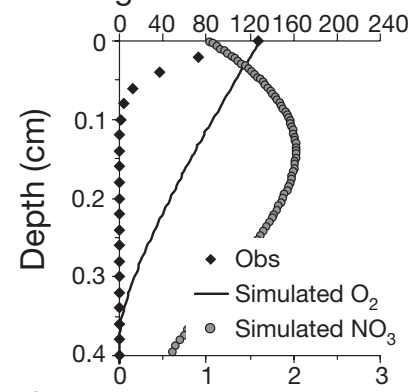

C5 Dec 01

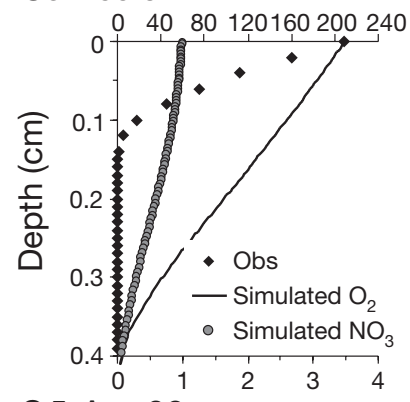

C5 Aug 02

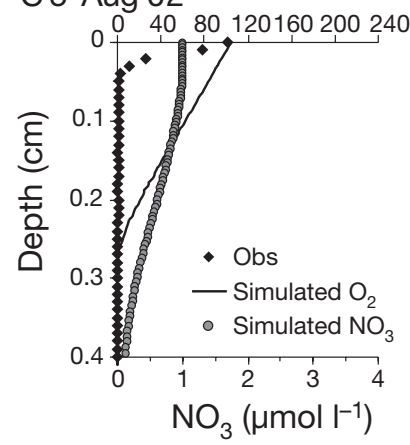

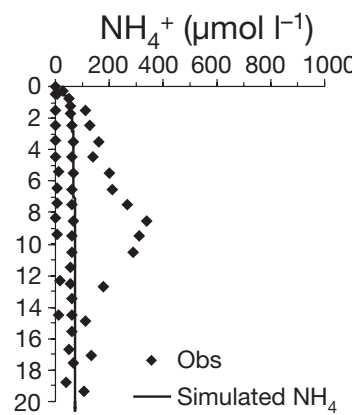
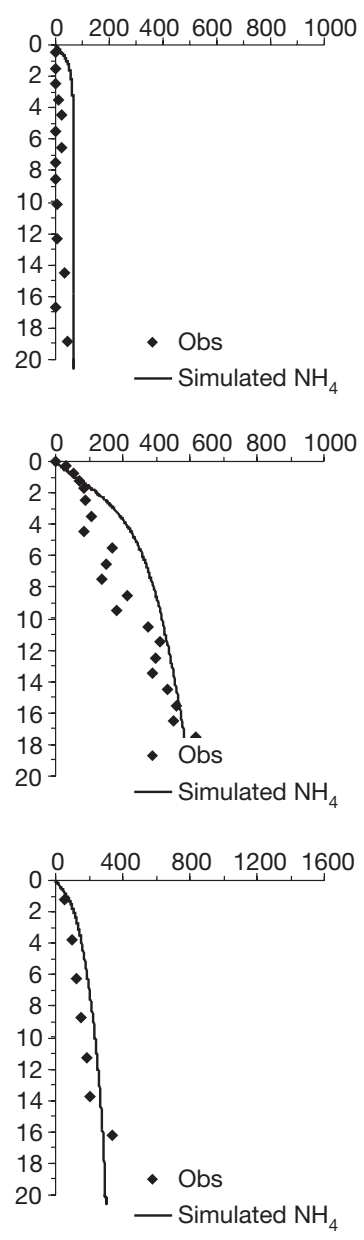
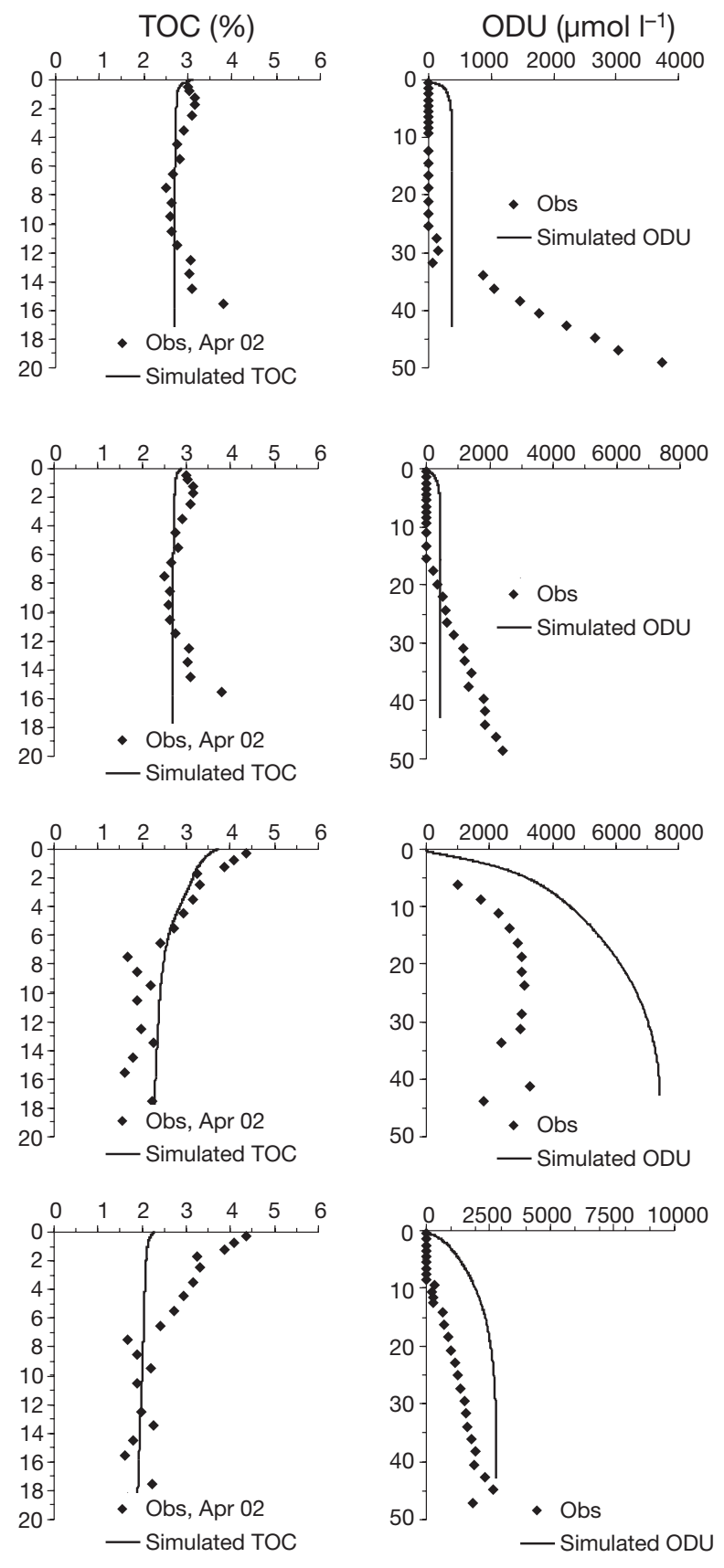

Fig. 4. In situ ( $\bullet$ ) and modeled (-) oxygen, ammonium, TOC, ODU and (o) simulated nitrate at Stns C4 and C5 during December 2001, August 2002 and May 2003. Parameters were fixed to better fit $\mathrm{NH}_{4}{ }^{+}$and ODU profiles. TOC profile measured during an intermediate cruise in April 2002 at both stations

input (Henriksen \& Kemp 1988, Herbert 1999, Kemp \& Dodds 2002).

In this system, temperature was found to be one of the main variables regulating the seasonal oxygen dynamics (Dedieu et al. 2007). Nitrifying bacteria generally exhibit optimal growth and activity during the late spring and summer when maximal temperatures and higher content of (fresh) organic matter in sedi- ments are found (e.g. Hansen 1980, Seitzinger et al. 1984). However, results showed that temperature varies inversely with nitrification and denitrification since higher rates were measured during cold periods. Therefore, temperature does not directly control nitrogen seasonal dynamics in this system.

With respect to the effect of bottom water oxygenation, some studies showed that potential nitrification 
Table 4. Model outputs with mean rates of carbon deposition on the surface sediment (MeanCarbonFlux) and \% of labile organic carbon (PartCarbonFluxFast) oxygen flux from the bottom water into the sediment $\left(\mathrm{MeanO}_{2}\right.$ Flux). Bold = boundary conditions, fixed through measured in situ conditions: $\mathrm{MeanBottomO_{2 }}$, Dedieu et al. (2007); ${ }_{1}$ eanBottomSO ${ }_{2}$ and $\mathrm{MeanBottomH}_{2} \mathrm{~S}$, $\mathrm{Metzerg}$ et al. (2007); MeanBioturbation and SedimentationRate, Schmidt et al. (2007) and Duport et al. (2007). Other parameter values obtained from literature: $\mathrm{NH}_{4}$ Adsorption, Soetaert et al. (1996) and $Q_{10}$, Thamdrup et al. (1998)

\begin{tabular}{|c|c|c|c|c|c|c|c|}
\hline & $\begin{array}{c}\text { C4 } \\
\text { Dec } 01\end{array}$ & $\begin{array}{c}\text { C5 } \\
\text { Dec } 01\end{array}$ & $\begin{array}{c}\text { C4 } \\
\text { Aug } 02\end{array}$ & $\begin{array}{c}\text { C5 } \\
\text { Aug } 02\end{array}$ & $\begin{array}{c}\text { C4 } \\
\text { May } 03\end{array}$ & $\begin{array}{c}\text { C5 } \\
\text { May } 03\end{array}$ & Unit \\
\hline MeanCarbonFlux & 12.0 & 38.4 & 55.2 & 108.0 & 52.8 & 108.0 & $\mathrm{mmol} \mathrm{C} \mathrm{m}{ }^{-2} \mathrm{~d}^{-1}$ \\
\hline PartCarbonFluxFast & 95 & 80 & 90 & 80 & 90 & 85 & $\%$ \\
\hline $\mathrm{MeanO}_{2}$ Flux & 11.5 & 26.9 & 38.4 & 51.7 & 33.4 & 54.6 & $\mathrm{mmol} \mathrm{O} \mathrm{m}^{-2} \mathrm{~d}^{-1}$ \\
\hline MeanBottomO $_{2}$ & 226 & 210 & 130 & 105 & 92 & 160 & $\mu \mathrm{mol} \mathrm{l} \mathrm{l}^{-1}$ \\
\hline MeanBottom $\mathrm{NO}_{3}{ }^{-}$ & 1 & 1 & 1 & 1 & 1 & 1 & $\mu \mathrm{mol} \mathrm{l} \mathrm{l}^{-1}$ \\
\hline MeanBottom $\mathrm{NH}_{4}{ }^{+}$ & 0 & 0 & 0 & 0 & 0 & 0 & $\mu \mathrm{mol} \mathrm{l}^{-1}$ \\
\hline MeanBottomSO $_{2}$ & 31 & 33 & 26 & 30 & 26 & 30 & $\mathrm{mmol} \mathrm{l}^{-1}$ \\
\hline MeanBottomH $\mathrm{H}_{2} \mathrm{~S}$ & 0 & 0 & 0 & 0 & 0 & 0 & $\mu \mathrm{mol} \mathrm{l} \mathrm{l}^{-1}$ \\
\hline TOCinfsed & 2.7 & 1.8 & 2.7 & 1.8 & 2.7 & 1.8 & $\%$ \\
\hline MeanBioturbation & 0.0033 & 0.0015 & 0.0082 & 0.0084 & 0.0032 & 0.0045 & $\mathrm{~cm}^{2} \mathrm{~d}^{-1}$ \\
\hline SedimentationRate & 0.0008 & 0.0005 & 0.0008 & 0.0005 & 0.0008 & 0.0005 & $\mathrm{~cm} \mathrm{~d}^{-1}$ \\
\hline MeanBottomTemperature & 9.6 & 9.6 & 23 & 23 & 18 & 18 & ${ }^{\circ} \mathrm{C}$ \\
\hline$R_{\text {nitrit }}$ & 1 & 1 & 10 & 10 & 10 & 10 & $\mathrm{~d}^{-1}$ \\
\hline$K S_{\text {Nitrif }}^{\mathrm{O}_{2}}$ & 10 & 10 & 10 & 10 & 10 & 10 & $\mu \mathrm{mol} \mathrm{O} \mathrm{O}^{-1}$ \\
\hline $\operatorname{Kin}_{\mathrm{ODU}}^{\mathrm{Nit}}$ & 3 & 0.6 & 1.7 & 0.5 & 7 & 0.55 & $\mu \mathrm{mol}$ ODU $\mathrm{l}^{-1}$ \\
\hline MaxODUoxidationSed & 600 & 200 & 800 & 1000 & 1000 & 600 & $\mathrm{~d}^{-1}$ \\
\hline$K s_{\text {ODUoxid }}^{\mathrm{O}_{2}}$ & 1 & 5 & 1 & 1 & 1 & 1 & $\mu \mathrm{mol} \mathrm{O} \mathrm{I}^{-1}$ \\
\hline cFDET20sed & 0.06 & 0.1 & 0.1 & 0.1 & 0.1 & 0.1 & $\mathrm{~d}^{-1}$ \\
\hline cSDET20sed & 0.001 & 0.001 & 0.001 & 0.001 & 0.001 & 0.001 & $\mathrm{~d}^{-1}$ \\
\hline$K s_{\text {OxicMin }}^{\mathrm{O}_{2}}$ & 1 & 1 & 1 & 1 & 1 & 1 & $\mu \mathrm{mol} \mathrm{O} \mathrm{I}^{-1}$ \\
\hline$K s_{\text {Denitrif }}^{\mathrm{NO}_{3}}$ & 1 & 1 & 100 & 350 & 80 & 220 & $\mu \mathrm{mol} \mathrm{NO} \mathrm{N}^{-1}$ \\
\hline $\mathrm{Kin}_{\mathrm{O}_{2}}^{\text {Denit }}$ & 1 & 0.1 & 0.1 & 0.1 & 0.1 & 0.1 & $\mu \mathrm{mol} \mathrm{O} \mathrm{O}_{2} \mathrm{l}^{-1}$ \\
\hline $\mathrm{Kin}_{\text {AnoxicMin }} \mathrm{NO}_{3}$ & 1 & 1 & 1 & 10 & 1 & 1 & $\mu \mathrm{mol} \mathrm{NO} \mathrm{N}^{-1}$ \\
\hline $\mathrm{Kin}_{\text {AnoxicMin }}^{\mathrm{O}_{2}}$ & 1 & 1 & 1 & 1 & 1 & 1 & $\mu \mathrm{mol} \mathrm{O} \mathrm{I}^{-1}$ \\
\hline
\end{tabular}

and denitrification began to decrease around 100 to $150 \mu \mathrm{mol} \mathrm{O} \mathrm{O}^{-1}$ in temperate coastal waters (Rysgaard et al. 1994, Kemp \& Dodds 2002). No such oxygen conditions were measured at our stations during the cruise periods (with minima around $150 \mu \mathrm{mol} \mathrm{O}_{2} \mathrm{l}^{-1}$ in August 2002 and May 2003); thus, oxygen limitation cannot explain the decrease of coupled nitrificationdenitrification rates during these warm periods.

Chemoautotrophic nitrifying bacteria are considered to be strictly aerobic and require free $\mathrm{O}_{2}$ for $\mathrm{NH}_{4}{ }^{+}$and $\mathrm{NO}_{2}{ }^{-}$oxidation. Consequently, growth of nitrifiers is restricted to the oxic layers of sediments and the limits of downward oxygen diffusion directly affect microbial populations, altering and limiting coupled nitrification-denitrification. (e.g. Lorenzen et al. 1998). Our data set and modelling suggest that fluctuation in oxygen penetration depth is related to nitrogen dynamics, especially at Stn C5 since the observed strong contraction of the oxic zone in August 2002 and May 2003 corresponded to the minimum nitrification and denitrification rates.
From model runs, nitrification and denitrification rates and their seasonal evolution appeared in accordance with field data where intensity of these processes was low, with minimum rates occurring during the warm periods of August 2002 and May 2003. Table 5 presents the overall contribution of the main pathways (denitrification, oxic and anoxic mineralization) in the sediments estimated by the model. Anoxic mineralization appeared significantly higher for organic matter cycling compared with denitrification and oxic mineralization at both stations. In August 2002 and May 2003 more than $80 \%$ of total mineralization occurred through anoxic routes. The remainder was essentially attributed to oxic mineralization since denitrification represented less than $1 \%$ of the organic matter degradation pathways. The model suggests that anoxic mineralization was higher at Stn C5 inside the farming area as compared with that at Stn $\mathrm{C} 4$ far from the shellfish zone. This could be related to the overall larger input of organic matter from shellfish farming activity. On a seasonal basis, winter was more favor- 
Table 5. Main processes contribution (\%) of organic matter mineralization: oxic mineralization (OxicMin), denitrification (Denit) and anoxic mineralization (AnoxicMin)

\begin{tabular}{|llrrr|}
\hline Stn & & Dec 01 & Aug 02 & May 03 \\
\hline C4 & \% OxicMin & 34 & 21 & 18 \\
& \% Denit & 1 & $<1$ & $<1$ \\
& \% AnoxicMin & 65 & 79 & 82 \\
C5 & \% OxicMin & 27 & 9 & 9 \\
& \% Denit & $<1$ & $<1$ & $<1$ \\
& \% AnoxicMin & 73 & 91 & 91 \\
\hline
\end{tabular}

able to oxic mineralization at both stations presumably due to lower inputs of very labile organic matter. The model also revealed that the major part of oxygen consumption was used to re-oxidize byproducts from anaerobic reactions, especially at Stn C5 during the warm periods (Table 6).

\section{Nitrogen and sulfur coupling}

At the lagoon scale, the higher sulfide content in surface sediments of Stn C5 (Metzger et al. 2007) suggest a higher sulfide inhibition of nitrification, which would be in agreement with the lower nitrification and coupled denitrification rates measured in this station. At Stn C4, sulfide concentration started to increase at about the $15 \mathrm{~cm}$ depth in August 2002 and $30 \mathrm{~cm}$ in December 2001 and April 2002. According to Metzger et al. (2007), this is due to the rapid sulfide interaction with reactive ferric minerals keeping sulfide low. This reduced amount of sulfide near the oxic zone may result in a lower inhibition of nitrification compared with Stn C5. Some studies suggested that manganese oxides could consume the potential pool of available $\mathrm{NH}_{4}{ }^{+}$to form $\mathrm{N}_{2}$ or $\mathrm{NO}_{3}{ }^{-}$(Luther et al. 1997, Hulth et al. 1999, Anschutz et al. 2000). However, neither $\mathrm{NO}_{3}^{-}$nor $\mathrm{Mn}^{2+}$ concentrations, required to support nitrification, were measured in significant amount in the anoxic zone of the sediments suggesting that this reaction did not occur.

Total $\mathrm{NH}_{4}{ }^{+}$fluxes were measured in benthic chambers $\left(0.196 \mathrm{~m}^{2}\right)$ in May 2003 (Thouzeau et al. 2007). Results showed a release of $\mathrm{NH}_{4}{ }^{+}$from the sediment at both stations. $\mathrm{NH}_{4}{ }^{+}$efflux was 6 times higher at the station inside the shellfish area $\left(8.23 \pm 0.53 \mathrm{mmol} \mathrm{N} \mathrm{m}{ }^{-2}\right.$ $\left.\mathrm{d}^{-1}\right)$ than outside $\left(1.5 \pm 0.71 \mathrm{mmol} \mathrm{N} \mathrm{m}^{-2}\right.$ $\mathrm{d}^{-1}$ ). This large measured $\mathrm{NH}_{4}^{+}$efflux is in accordance with the large anaerobic
Table 6. Percent (\%) distribution of $\mathrm{O}_{2}$ demand processes among 3 different processes that require oxygen: $\mathrm{O}_{2}$ used in aerobic mineralization $\left(\mathrm{O}_{2} \mathrm{Min}\right), \mathrm{O}_{2}$ used by nitrifying bacteria $\left(\mathrm{O}_{2} \mathrm{Nit}\right)$ and $\mathrm{O}_{2}$ used to oxidize the reduced products $\left(\mathrm{O}_{2} \mathrm{ODU}\right)$

\begin{tabular}{|llrrr|}
\hline Stn & OxicMin & Dec 01 & Aug 02 & May 03 \\
\hline C4 & $\% \mathrm{O}_{2}$ Min & 36 & 30 & 28 \\
& $\% \mathrm{O}_{2} \mathrm{Nit}$ & 7 & 1 & 2 \\
& $\% \mathrm{O}_{2} \mathrm{ODU}$ & 57 & 69 & 70 \\
C5 & $\% \mathrm{O}_{2} \mathrm{Min}$ & 38 & 18 & 18 \\
& $\% \mathrm{O}_{2} \mathrm{Nit}$ & $<1$ & $<1$ & $<1$ \\
& $\% \mathrm{O}_{2} \mathrm{ODU}$ & 62 & 82 & 82 \\
\hline
\end{tabular}

mineralization at both stations and measured low rates of nitrification, which prevents ammonium consumption. Model outputs in May 2003 showed a similar trend with larger $\mathrm{NH}_{4}{ }^{+}$fluxes evident in the shellfish area (Stn C5) compared with the reference station (Stn C4), but the absolute flux values were larger than those from benthic chambers (13.8 and $6.1 \mathrm{mmol} \mathrm{N} \mathrm{m}^{-2}$ $\mathrm{d}^{-1}$ at Stns C5 and C4, respectively). Model outputs also show larger $\mathrm{NH}_{4}{ }^{+}$and ODU concentrations in the sediment porewaters (Fig. 2). This indicates a general overestimation of anoxic processes in the model that could be due to a temporal decoupling between aerobic and anaerobic mineralization processes. Another set of simulations with adjustments of $\mathrm{NH}_{4}{ }^{+}$and ODU profiles was achieved at both stations for the 2 distinct seasons of December 2001 and August 2003. The results show a large reduction of oxic and anoxic rates, which are incompatible with the observation made by microelectrodes, and have a lower impact on nitrification and denitrification rates (Table 7). This decoupling of oxic and anoxic processes could be due to the difference in residence time in the oxic layer (a few days) compared with anoxic processes that occur deeper in the sediment and have a longer reaction time (a few months). There is also a seasonal pattern for the decou-

Table 7. Model outputs of the mean carbon and oxygen fluxes $\left(\mathrm{mmol} \mathrm{C} \mathrm{m} \mathrm{m}^{-2} \mathrm{~d}^{-1}\right)$ and nitrification and denitrification rates $\left(\mathrm{mmol} \mathrm{N} \mathrm{m} \mathrm{N}^{-2} \cdot \mathrm{d}^{-1}\right)$ from simulations of $\mathrm{NH}_{4} / \mathrm{TOC}$ and $\mathrm{O}_{2} /$ TOC profiles

\begin{tabular}{|c|c|c|c|c|c|}
\hline & \multicolumn{2}{|c|}{ Stn $\mathrm{C} 4$} & \multicolumn{2}{|c|}{ Stn C5 } & \multirow[t]{2}{*}{ Simulation } \\
\hline & Dec 01 & Aug 02 & Dec 01 & Aug 02 & \\
\hline Mean C Flux & $\begin{array}{r}8.16 \\
12.00\end{array}$ & $\begin{array}{r}7.20 \\
55.20\end{array}$ & $\begin{array}{r}7.20 \\
38.40\end{array}$ & $\begin{array}{r}7.20 \\
108.00\end{array}$ & $\begin{array}{l}\mathrm{NH}_{4} / \mathrm{ODU} \\
\mathrm{O}_{2} / \mathrm{TOC}\end{array}$ \\
\hline Mean $\mathrm{O}_{2}$ Flux & $\begin{array}{r}8.30 \\
11.50\end{array}$ & $\begin{array}{r}7.11 \\
38.40\end{array}$ & $\begin{array}{r}5.72 \\
26.90\end{array}$ & $\begin{array}{r}6.50 \\
51.70\end{array}$ & $\begin{array}{l}\mathrm{NH}_{4} / \mathrm{ODU} \\
\mathrm{O}_{2} / \mathrm{TOC}\end{array}$ \\
\hline Nitrification & $\begin{array}{l}0.879 \\
0.400\end{array}$ & $\begin{array}{l}0.277 \\
0.143\end{array}$ & $\begin{array}{l}0.061 \\
0.032\end{array}$ & $\begin{array}{l}0.053 \\
0.014\end{array}$ & $\begin{array}{l}\mathrm{NH}_{4} / \mathrm{ODU} \\
\mathrm{O}_{2} / \mathrm{TOC}\end{array}$ \\
\hline Denitrification & $\begin{array}{l}0.110 \\
0.086\end{array}$ & $\begin{array}{l}0.023 \\
0.020\end{array}$ & $\begin{array}{l}0.027 \\
0.017\end{array}$ & $\begin{array}{l}0.008 \\
0.009\end{array}$ & $\begin{array}{l}\mathrm{NH}_{4} / \mathrm{ODU} \\
\mathrm{O}_{2} / \mathrm{TOC}\end{array}$ \\
\hline
\end{tabular}


pling of oxic and anoxic mineralization processes. This discrepancy could be partly explained by large variations in macrofaunal activity as shown by Schmidt et al. (2007). Indeed, those authors displayed clear variations in the seasonal pattern and vertical distribution of sediment reworking intensities in the Thau Lagoon sediments that could influence transport of particulate and dissolved species. Modelling of reactive species took into account bioturbation, but not its variation with depth or time that could explain the $\mathrm{NH}_{4}{ }^{+}$and ODU profiles discrepancies. This decoupling emphasizes the necessity to consider the nonstationary state in perturbed sediments to better estimate the anoxic mineralization rates and improve the general representation of solutes profiles. The in situ data set and model information also suggest that oxygen availability in the sediment (oxic zone thickness) partially controls the seasonal variation of the nitrogen cycle, but plays a minor role in the average intensity of nitrification/denitrification at each station. Among the different processes that limit nitrification and denitrification, sulfide inhibition seemed to be significant in this lagoon whereas ammonium concentrations in pore waters and bottom water oxygenation were not limiting. These measurements also revealed that nitrification and denitrification intensity were negatively correlated with the organic carbon mineralization due to the sulfide production in organic-rich sediments.

Acknowledgements. We thank B. Bombled who deployed the profiler and dived during cruises at the Thau Lagoon; G. Sarazin, D. Jézéquel, J.-J. Bourrand, R. Graille, B. de Ligondès and $\mathrm{F}$. Zuberer for their assistance and diving during profiler deployment; and the crew of the 'Chlamys J.-L. Guillou'. We thank R. C. Aller for his scientific input. We also thank the IFREMER Station of Sète for providing laboratory space and the research boat. This work was supported by a grant from the PNEC-ART1 (Microbent) and the Laboratoire des Sciences du Climat et de l'Environnement (CEA-CNRS), and by the EU commission (STREP COBO; contract number GOCE-CT-2003-505564). This is LSCE contribution number 2809.

\section{LITERATURE CITED}

Anderson LG (1979) Simultaneous spectrophotometric determination of nitrite and nitrate by flow injection analysis. Anal Chem Acta 110:123-128

Anschutz P, Sundby B, Lefrançois L, Luther III GW, Mucci A (2000) Interactions between metal oxides and species of nitrogen and iodine in bioturbated marine sediments. Geochim Cosmochim Acta 64:2751-2763

Anschutz P, Chaillou G, Lecroart P (2007) Phosphorus diagenesis in sediment of the Thau Lagoon. Estuar Coast Shelf Sci 72:447-456

Bendschneider K, Robinson RJ (1972) A new spectrometric method for determination of nitrite in sea water. J Mar Res 11:87-96
Berg P, Risgaard-Petersen N, Rysgaard S (1998) Interpretation of measured concentration profiles in sediment pore water. Limnol Oceanogr 43:1500-1510

Berner RA (1980) Early diagenesis: a theoretical approach. Princeton University Press, Princeton, NJ

Blackburn TH, Sørensen J (1988) Nitrogen cycling in coastal marine environments. John Wiley and Sons, New York

Boudreau BP (1997) Diagenetic models and their implementation: modelling transport and reactions in aquatic sediments. Springer Verlag, Berlin

Brandes JA, Devol AH (1995) Simultaneous nitrate and oxygen respiration in coastal sediments: evidence for discrete diagenesis. J Mar Res 53:771-797

Christensen JP, Murray JW, Devol AH, Codispoti LA (1987) Denitrification in continental shelf sediments has major impact on the oceanic nitrogen budget. Global Biogeochem Cycles 1:97-116

Christensen PB, Glud RN, Dalsgaard T, Gillespie P (2003) Impacts of longline mussel farming on oxygen and nitrogen dynamics and biological communities of coastal sediments. Aquaculture 218:567-588

Dalsgaard T, Canfield DE, Petersen J, Tramdrup B, AcuñaGonzález $\mathrm{J}$ (2003) $\mathrm{N}_{2}$ production by the anammox reaction in the anoxic water column of Golfo Dulce, Costa Rica. Nature 422:606-608

Dalsgaard T, Thamdrup B, Canfield DE (2005) Anaerobic ammonium oxidation (anammox) in the marine environment. Res Microbiol 156:457-464

Dedieu K, Rabouille C, Thouzeau G, Jean F, Chauvaud L, Clavier J, Mesnage V, Ogier S (2007) Benthic O2 distribution and dynamics in a Mediterranean lagoon (Thau, France): an in situ microelectrode study. Estuar Coast Shelf Sci 72:393-405

Devol AH (1991) Direct measurements of nitrogen gas fluxes from continental shelf sediments. Nature 349:319-321

Duport E, Gilbert F, Poggiale JC, Dedieu K, Rabouille C, Stora G (2007) Benthic macrofauna and sediment reworking quantification in contrasted environments in the Thau Lagoon. Estuar Coast Shelf Sci 72:522-533

Espitalié J, Derro G, Marquis F (1985) La pyrolyse Rock-Eval et ses applications. Rev Inst Fr Pétrole 40:563-579

Eyre B, Ferguson AJP (2002) Sediment biogeochemical indicators for defining sustainable nutrient loads to coastal ecosystems. Proceedings of Coast to Coast 2002 - 'Source to Sea'. Tweed Heads, p 101-104

Froelich PN, Klinkhammer GP, Bender ML, Luedtke NA and 6 others (1979) Early oxidation of organic matter in pelagic sediments of the eastern equatorial Atlantic: suboxic diagenesis. Geochim Cosmochim Acta 43:1075-1090

Gilbert F, Souchu P, Bianchi M, Bonin P (1997) Influence of shellfish farming activities on nitrification, nitrate reduction to ammonium and denitrification at the water-sediment interface of the Thau lagoon, France. Mar Ecol Prog Ser 151:143-153

Hall POJ, Aller RC (1992) Rapid, small-volume flow injection analysis for SCO2 and $\mathrm{NH} 4+$ in marine and freshwaters. Limnol Oceanogr 37:1113-1119

Hamon PY, Tournier H (1981) Estimation de la biomasse en culture dans l'etang de Thau. Sci Pêche 313:1-23

Hansen JI (1980) Potential nitrification in marine sediments. MSc thesis, University of Aarhus

Henriksen K, Kemp WM (1988) Nitrification in estuarine and coastal marine sediments. In: Blackburn TH, Sørensen J (eds) Nitrogen cycling in coastal marine environments. John Wiley and Sons, Chichester, p 207-249

Herbert RA (1999) Nitrogen cycling in coastal marine ecosystems. FEMS Microbiol Rev 23:563-590 
Hesslein RH (1976) An in-situ sampler for close interval pore water studies. Limnol Oceanogr 21:912-914

Hulth S, Aller RC, Gilbert F (1999) Coupled anoxic nitrification/manganese reduction in marine sediments. Geochim Cosmochim Acta 63:49-66

Hulthe G, Hulth S, Hall POJ (1998) Effect of oxygen on degradation rate of refractory and labile organic matter in continental margin sediments. Geochim Cosmochim Acta 62: $1319-1328$

Hyacinthe C, Anschutz P, Carbonel P, Jouanneau JM, Jorissen FJ (2001) Early diagenetic processes in the muddy sediments of the Bay of Biscay. Mar Geol 177:111-128

Jensen K, Revsbech NP, Nielsen LP (1993) Microscale distribution of nitrification activity in sediment determined with a shielded microsensor for nitrate. Appl Environ Microbiol 59: $3287-3296$

Joye SB, Hollibaugh JT (1995) Influence of sulfide inhibition of nitrification on nitrogen regeneration in sediments. Science 270:623-625

Kemp MJ, Dodds WK (2002) The influence of ammonium, nitrate, and dissolved oxygen concentrations on uptake, nitrification, and denitrification rates associated with prairie stream substrata. Limnol Oceanogr 47:1380-1393

Klemedtsson L, Svensson BH, Rosswall T (1988) A method of selective inhibition to distinguish between nitrification and denitrification as sources of nitrous oxide in soil. Biol Fertil Soils 6:106-111

Klemedtsson L, Hansson G, Mossier A (1990) The use of acetylene for the quantification of $\mathrm{N}_{2}$ and $\mathrm{N}_{2} \mathrm{O}$ production from biological processes in soil. In: Revsbech NP, Sørensen J (eds) Denitrification in soil and sediment. Plenum Press, New York, p 167-180

Kuypers MMM, Sliekers AO, Lavik G, Schmid M and 5 others (2003) Anaerobic ammonium oxidation by anammox bacteria in the Black Sea. Nature 422:608-611

Lohse L, Malschaert JFP, Slomp CP, Helder W, Raaphorst WV (1993) Nitrogen cycling in North Sea sediments: interaction of denitrification and nitrification in offshore and coastal areas. Mar Ecol Prog Ser 101:283-296

Lorenzen J, Larsen LH, Kjaer T, Revsbech NP (1998) Biosensor determination of the microscale distribution of nitrate, nitrate assimilation, nitrification, and denitrification in a diatom-inhabited freshwater sediment. Appl Environ Microbiol 64:3264-3269

Luther I, George W, Sundby B, Lewis BL, Brendel PJ, Silverberg $N$ (1997) Interactions of manganese with the nitrogen cycle: alternative pathways to dinitrogen. Geochim Cosmochim Acta 61:4043-4052

Mesnage V, Ogier S, Bally G, Disnar JR, Lottier N, Dedieu K, Rabouille C, Copard Y (2007) Nutrient dynamics at the

Editorial responsibility: Howard Browman (Associate Editorin-Chief), Storebø, Norway sediment-water interface in a Mediterranean lagoon (Thau, France): influence of biodeposition by shellfish farming activities. Mar Environ Res 63:257-277

Metzger E, Simonucci C, Viollier E, Sarazin G, Prevot F, Jezequel D (2007) Benthic response to shellfish farming in Thau lagoon: pore water signature. Estuar Coast Shelf Sci 72: 406-419

Revsbech NP (1989) An oxygen microsensor with a guard cathode. Limnol Oceanogr 34:474-478

Risgaard-Petersen N, Rysgaard S, Nielsen LP, Revsbech NP (1994) Diurnal variation of denitrification and nitrification in sediments colonised by benthic microphytes. Limnol Oceanogr 39:573-579

Rysgaard S, Risgaard-Petersen N, Sloth NP, Jensen K, Nielsen LP (1994) Oxygen regulation of nitrification and denitrification in sediments. Limnol Oceanogr 39:1643-1652

Rysgaard S, Risgaard-Petersen N, Sloth NP (1996) Nitrification, denitrification, and nitrate ammonification in sediments of two coastal lagoons in Southern France. Hydrobiologia 329: 133-141

Schmidt S, Jouanneau JM, Weber O, Lecroart P, Radakovitch O, Gilbert F, Jezequel D (2007) Sedimentary processes in the Thau Lagoon (France): from seasonal to century time scales. Estuar Coast Shelf Sci 72: $534-542$

Seitzinger SP, Nixon SW, Pilson ME (1984) Denitrification and nitrous oxide production in a coastal marine ecosystem. Limnol Oceanogr 29:73-83

Soetaert K, Herman PMJ, Middelburg JJ (1996) A model of early diagenetic processes from the shelf to abyssal depths. Geochim Cosmochim Acta 60:1019-1040

Thamdrup B, Hansen JW, Jørgensen BB (1998) Temperature dependence of aerobic respiration in a coastal sediment. FEMS Microbiol Ecol 25:189-200

Thouzeau G, Grall J, Clavier J, Chauvaud L and 5 others (2007) Spatial and temporal variability of benthic biogeochemical fluxes associated with macrophytic and macrofaunal distributions in the Thau lagoon (France). Estuar Coast Shelf Sci 72:432-446

Treguer P, Le Corre P (1975) Manuel d'analyse des sels nutritifs dans l'eau de mer (utilisation de l'autoAnalyseur II Technicon), 2nd edn. Laboratoire d'océanographie chimique, UBO, Brest

Ullman WJ, Aller RC (1982) Diffusion coefficients in nearshore marine sediments. Limnol Oceanogr 27: $552-556$

Usui T, Koike I, Ogura N (2001) $\mathrm{N}_{2} \mathrm{O}$ production, nitrification and denitrification in an estuarine sediment. Estuar Coast Shelf Sci 52:769-781

Submitted: December 15, 2005 Accepted: May 6, 2007

Proofs received from author(s): September 13, 2007 